OAK RIDGE

NATIONAL LABORATORY

MANAGED BY UT-BATTELLE

FOR THE DEPARTMENT OF ENERGY

\title{
Homeowner Decision Making and Behavior Relating to Deep Home Retrofits
}

\author{
Results of Homeowner Interviews
}

\author{
A. K. Wolfe \\ T. P. Hendrick
}

September 2012

(updated September 2013)

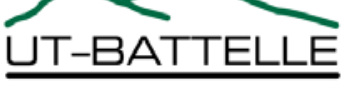




\section{DOCUMENT AVAILABILITY}

Reports produced after January 1, 1996, are generally available free via the U.S. Department of Energy (DOE) Information Bridge.

Web site http://www.osti.gov/bridge

Reports produced before January 1, 1996, may be purchased by members of the public from the following source.

National Technical Information Service

5285 Port Royal Road

Springfield, VA 22161

Telephone 703-605-6000 (1-800-553-6847)

TDD 703-487-4639

Fax 703-605-6900

E-mail info@ntis.fedworld.gov

Web site http://www.ntis.gov/support/ordernowabout.htm

Reports are available to DOE employees, DOE contractors, Energy Technology Data Exchange (ETDE) representatives, and International Nuclear Information System (INIS) representatives from the following source.

Office of Scientific and Technical Information

P.O. Box 62

Oak Ridge, TN 37831

Telephone 865-576-8401

Fax 865-576-5728

E-mail reports@adonis.osti.gov

Web site http://www.osti.gov/contact.html

This report was prepared as an account of work sponsored by an agency of the United States Government. Neither the United States Government nor any agency thereof, nor any of their employees, makes any warranty, express or implied, or assumes any legal liability or responsibility for the accuracy, completeness, or usefulness of any information, apparatus, product, or process disclosed, or represents that its use would not infringe privately owned rights. Reference herein to any specific commercial product, process, or service by trade name, trademark, manufacturer, or otherwise, does not necessarily constitute or imply its endorsement, recommendation, or favoring by the United States Government or any agency thereof. The views and opinions of authors expressed herein do not necessarily state or reflect those of the United States Government or any agency thereof. 


\title{
HOMEOWNER DECISION MAKING AND BEHAVIOR RELATING TO DEEP HOME RETROFITS
}

RESULTS OF HOMEOWNER INTERVIEWS

\author{
A. K. Wolfe \\ T. P. Hendrick
}

September 2012

(updated September 2013)

\section{Prepared for}

U. S. Department of Energy

Office of Energy Efficiency and Renewable Energy

Building Technologies Program

\author{
Prepared by \\ Environmental Sciences Division \\ OAK RIDGE NATIONAL LABORATORY \\ P.O. Box 2008, Oak Ridge, TN 37831 \\ managed by \\ UT-Battelle, LLC \\ for the \\ U.S. DEPARTMENT OF ENERGY \\ under Contract No. DE-AC05-00OR22725
}


[THIS PAGE LEFT BLANK INTENTIONALLY] 
Table of Contents

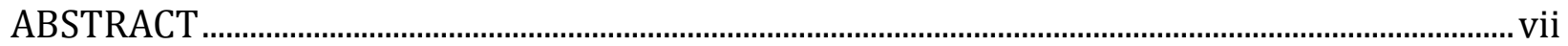

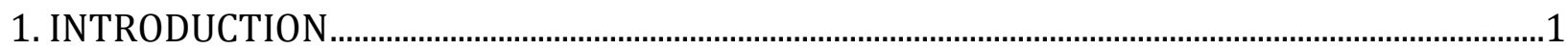

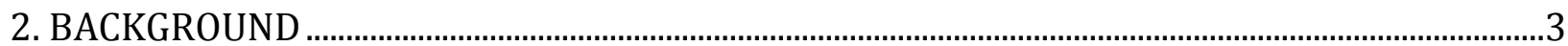

2.1. Residential retrofit initiatives..................................................................................................

2.2. The role of homeowners in analyses of residential retrofit initiatives................................7

2.3. A behavioral gap-homeowner decision making ...................................................................8

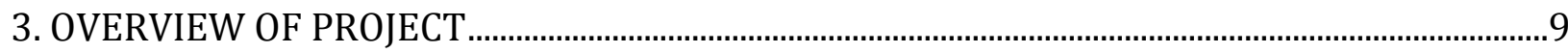

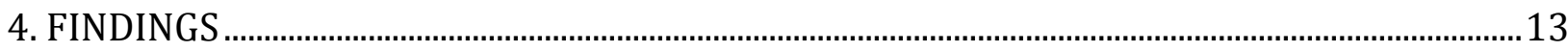

4.1. Homeowners who implemented all recommended measures ..........................................13

4.2. Homeowners who implemented some measures ................................................................... 14

4.3. Homeowners who implemented no measures .......................................................................... 15

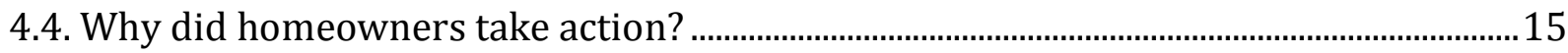

4.5. Why did some homeowners not take action? ….................................................................16

4.6. What were the homeowners' experiences in implementing recommendations? ........17

4.7. What do the homeowners advise? ...........................................................................................

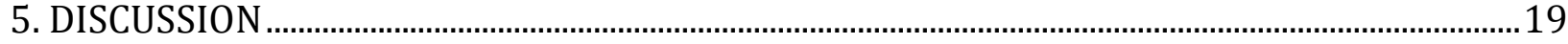

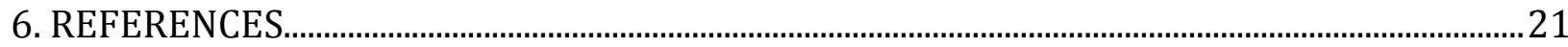

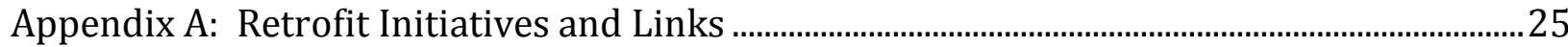

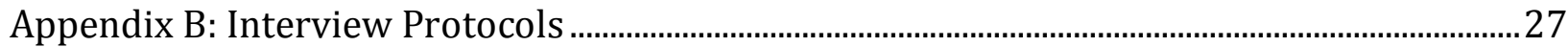

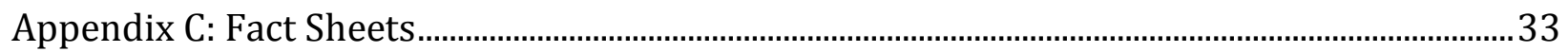


(THIS PAGE LEFT BLANK INTENTIONALLY) 


\section{LIST OF TABLES}

Table 1: Retrofit initiatives across the U.S.............................................

Table 2: Retrofit initiatives, by funding source and administration .........................

Table 3: Overview of retrofit initiatives, by objective, approach, and measure of success* ......6

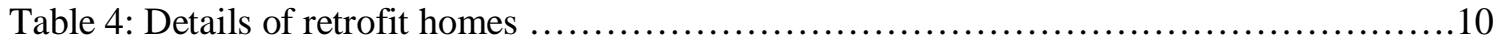

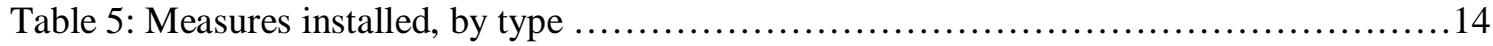


(THIS PAGE LEFT BLANK INTENTIONALLY) 


\begin{abstract}
Existing homes present an enormous, largely untapped potential for energy savings. The U.S. Department of Energy (DOE), utilities, and other organizations around the country have launched many initiatives intended to achieve significant energy savings through home retrofits — or energy-saving home improvements. Retrofit programs vary in their specific objectives, the kind of homes or homeowners targeted, their approaches, the metrics for their "success," and various measures of their effectiveness. Each initiative explicitly or implicitly reflects ideas or assumptions about "what it takes" for homeowners to participate in energy-saving retrofit programs, go through with audits, install recommended energysaving measures, and/or achieve desired or predicted energy savings. Yet, there is not enough research to identify with certainty the approaches likely to work best for a particular population in a particular setting. The interrelated tendencies to focus on actions homeowners take (e.g., via participation rates) and/or to make assumptions about homeowners' motivations contributes to this knowledge gap. This report seeks to shrink this knowledge gap by focusing on homeowner decision making. In particular, it focuses on a set of homeowners who agreed to participate in a technical deep-home retrofit project wherein they would implement a variety of measures (at their own personal cost) and have the effectiveness of those measures monitored for a year after installation.

This behavioral study complements the technology-oriented deep-home retrofit study by providing a necessary linkage between technologies and their use. Neither the existence of energy-saving technologies nor the capability to achieve substantial energy savings automatically translate into homeowner action. Similarly, the research described in this report did not assume that homeowners' decisions are determined by energy savings, monetary costs, or payback periods. Rather, it left open the questions of why homeowners undertake deep energy-saving retrofits, and why they may select some energy-saving measures and not others. This study starts to weave technology and action together by focusing on homeowners' responses to the following three questions:
\end{abstract}

- What affects homeowners' decisions?

- What do homeowners experience throughout what might be termed the retrofitting lifecycle?

- What do homeowners recommend for other homeowners? For contractors? For utilities and government agencies? 
(THIS PAGE LEFT BLANK INTENTIONALLY) 


\section{INTRODUCTION}

Existing homes present an enormous, largely untapped potential for energy savings. By 2020, approximately 3.25 of the 99.5 quads of energy used annually in the United States could be saved through residential building energy savings (Bianchi et al. 2011, Granade et al. 2009). An estimated $40 \%$ reduction in energy use of the average household and approximately 160 million metric tons of prevented $\mathrm{CO}_{2}$ emissions could be obtained from the approximately 130 million single-family homes in America (Middle Class Task Force). The U.S. Department of Energy (DOE), utilities, and other organizations around the country have launched many initiatives intended to achieve significant energy savings through home retrofits-or energy-saving home improvements. Note that the initiatives of particular relevance here focus on homeowners who would be responsible for paying at least some fraction of the costs for audits, equipment, and energy-saving measure installation, and not low-income households or situations where homeowners are not responsible for financing retrofits themselves. Retrofit programs vary in their specific objectives, the kind of homes or homeowners targeted, their approaches, and the metrics for "success." They also vary in their effectiveness, as gauged by participation rates, efficiency measures installed, and energy savings achieved.

The initiatives explicitly or implicitly reflect ideas or assumptions about "what it takes" for individual homeowners or collections of homeowners (e.g., in neighborhoods) to participate in energy-saving retrofit programs, go through with audits, install recommended energy-saving measures, and/or achieve desired or predicted energy savings. Because of their variety, initiatives constitute natural experiments in the extent to which such factors as financial costs or payback periods, financial incentives or rebates, financing arrangements, pledges or competitions, or particular combinations of energy efficiency measures prove effective in achieving participation, implementation, or energy-saving goals. While there is a growing body of experience and literature on these issues, there is not enough research to identify with certainty the approaches likely to work best for a particular population in a particular setting. The interrelated tendencies to focus on actions homeowners take (e.g., via participation rates) and/or to make assumptions about homeowners' motivations contributes to this knowledge gap.

This report seeks to shrink this knowledge gap by focusing on homeowner decision making. The research described in this report did not assume that homeowners' decisions are determined by energy savings, monetary costs, or payback periods. Rather, it left open the questions of why homeowners undertake deep energy-saving retrofits, and why they may select some energysaving measures and not others. It allowed for the possibility that factors such as comfort, aesthetics, environmental ethos, or others could sway homeowner choices. By analyzing the factors that influence homeowner decisions, we seek to gain insights that ultimately can contribute to achieving substantial energy savings nationwide through retrofits to existing homes.

The homeowners described in this report are a small, atypical group who volunteered to participate in a separate, deep home retrofit research study (Boudreaux et al. 2012; Boudreaux, Biswas, and Jackson 2012). That study was technology-oriented. It had a goal of achieving 30$50 \%$ energy savings using a whole-house approach to assessing potential savings, making comprehensive recommendations to homeowners on the technological measures they could take to achieve those savings, and measuring and monitoring baseline and post-retrofit results for up to a year. To be accepted into the study, homeowners had to be willing to pay for the efficiency measures installed, a sum initially estimated to be on the order of $\$ 10,000-\$ 20,000$. That these 
homeowners were willing to participate in a research study and invest substantial sums in energyefficiency measures make them a distinctive group.

While the homeowners were an atypical group, the homes selected for the technical study deliberately were typical homes that happened to be very energy-inefficient. A key precept of the behavioral study reported in this document was that insights gained by analyzing this sample of homeowners could help the DOE and utilities develop and implement effective deep-home retrofit initiatives that would appeal to a broad set of homeowners who also live in typical homes. The sample homeowner group is akin to so-called "first adopters," except that they are adopting a concept or approach that entails multiple technologies instead of adopting a particular technology or practice. Secondarily, this behavior study aimed to provide information that homeowners can use to strive for deep energy savings (30-50\%) rather than the lesser savings associated with more commonplace energy-saving retrofit initiatives.

Thus, this behavioral study complements the technology-oriented deep-home retrofit study by providing a necessary linkage between technologies and their use. Neither the existence of energy-saving technologies nor the capability to achieve substantial energy savings automatically translate into homeowner action. This study starts to weave technology and action together by focusing on the following three questions:

- What affects homeowners' decisions?

- What do homeowners experience throughout what might be termed the retrofitting lifecycle?

- What do homeowners recommend for other homeowners? For contractors? For utilities and government agencies?

The report begins by providing some background information about initiatives that seek to achieve energy savings through retrofits - or improvements - to existing homes and noting what we term a behavioral gap evident in most of these initiatives. Then, the report describes the overall objectives and approach we took in the behavioral study, our findings, and analyses. The concluding discussion incorporates suggestions for future initiatives and further inquiry.

Appendices provide website links associated with numerous home retrofit initiatives across the country, copies of the interview protocols that guided our primary data collection, and fact sheets for the five homes in which major retrofits were implemented during the course of this study. Fact sheets comprise concise summaries that combine technological information with insights about homeowners' perspectives. 


\section{BACKGROUND}

Energy consumption in the United States reached 99.5 quads in 2008. Of the 21.54 quads used by the building sector, 54\% was used by residential buildings (Bianchi et al. 2011). Granade et al. (2009) analyzed the costs and benefits of retrofits using Home Energy Saver software and data from the Residential Energy Consumption Survey. They determined that the existing home market has the potential for $28 \%$ reduction in energy use (i.e., 3.25 quads) by 2020 or about $\$ 41$ billion in energy savings.

Energy efficiency programs typically focus on installation of single measures or a set of measures aimed at reducing buildings' energy use, especially insulation, caulking, and upgrading heating, ventilation, and air conditioning (HVAC) systems or appliances. Sweatman and Managan (2010) examined American and international studies and found that such measures can reduce energy use in existing buildings by 20 to $50 \%$. Most studies focus on what Leiserowitz et al. (2009) call energy-efficiency behaviors (occasional actions that can substantially affect energy use, such as insulating or caulking, buying air conditioners or water heaters, etc.) or energy-conservation behaviors (day-to-day actions like turning off lights, adjusting thermostats, etc.).

More recently, buildings researchers have focused on achieving deeper savings from retrofits through a more methodical approach, using diagnostic methods to determine which combination of measures can achieve the greatest savings. Deep retrofits look at the whole house as a single system, i.e., all parts of the house (envelope, mechanical systems, and other interior elements such as lighting and appliances) that affect energy consumption. There is no single definition of what constitutes a "deep" retrofit. Definitions typically are couched in terms of post-retrofit energy savings, where "deep" savings range from 30 to 75\% (Walker et al. 2012). For the purposes of this report, in alignment with the technical study with which this project was associated — and with the information provided to participating homeowners, a deep retrofit aims to achieve 30 to $50 \%$ energy savings ${ }^{1}$.

\subsection{Residential retrofit initiatives}

DOE, utilities, states, and municipalities have initiated many retrofit programs, generally with the goals of either achieving a set number of retrofits and/or achieving set energy and $\mathrm{CO}_{2}$ savings. Table 1 lists major retrofit projects currently underway around the country. While the list is not exhaustive, it captures the bulk of federal, state, and utility-led initiatives. The initiatives vary from installation of limited retrofit measures to whole-house-oriented deep home retrofits.

When analyzed by funding source and by who administers the initiatives, the diversity among the programs becomes clear. While approximately one-third of initiatives have been federally funded, many others are funded by utilities. Municipalities have funded fewer initiatives, while state and private sources fund one each of these initiatives. Table 2 shows the initiatives by funding source and administration.

\footnotetext{
${ }^{1}$ A different question raised during the course of the behavioral study that we did not investigate is the extent to which homeowners conceive of deep retrofits in those same energy-saving terms. Do they care more about a particular percentage of energy that potentially can be saved or, more broadly, about saving a lot of energy, for instance? And, to what extent do such distinctions in how homeowners frame their retrofit efforts influence decisions about which measures to install?
} 
Table 1: Retrofit initiatives across the U.S.

\begin{tabular}{|c|c|}
\hline \multicolumn{2}{|c|}{ Retrofit Initiatives } \\
\hline 1. & Green Codes Task Force: New York, NY \\
\hline 2. & Residential Energy Conservation Ordinance (RECO): Berkeley, CA \\
\hline 3. & Energy Conservation Audit and Disclosure (ECAD) Ordinance: Austin, TX \\
\hline 4. & Clean Energy Works Portland: Portland, OR \\
\hline 5. & Community Mobilization Initiative: New Bedford, MA \\
\hline 6. & Marshfield Energy Challenge: Marshfield, MA \\
\hline 7. & Colorado Retrofit Ramp-Up program: Boulder County, $\mathrm{CO}$ \\
\hline 8. & Green Retrofit Initiative: San Antonio, TX \\
\hline 9. & Greenworks Philadelphia: Philadelphia, PA \\
\hline & Better Buildings Greensboro: Greensboro, NC \\
\hline & Long Island Green Homes program: Babylon, NY \\
\hline & State Energy Program \\
\hline & EnergyWorks KC: Kansas City, MO \\
\hline & Palm Desert Energy Partnership Set to Save program: Palm Desert, CA \\
\hline & CPS Energy Savers program: San Antonio, TX \\
\hline & Arizona Public Service Company \\
\hline & Salt River Project \\
\hline & Tucson Electric Power: Tucson, AZ \\
\hline & Xcel Energy Company: CO \\
\hline & Fort Collins Utilities: Fort Collins, co \\
\hline & Southwestern Public Service Company: NM \\
\hline & New Mexico Gas Company \\
\hline & Nevada Power Company \\
\hline & Sierra Pacific Power Company: NV \\
\hline & Rocky Mountain Power Company wattsmart energy efficiency program: UT \\
\hline & Questar Gas Company ThermWise program: UT \\
\hline 27. & Energy Impact Illinois Residential Retrofit Program: Chicago and Rockford, IL \\
\hline & Flagstaff Residential Energy Retrofit Program: Flagstaff, AZ \\
\hline & TVA Energy Right program \\
\hline Deep & Retrofit Initiatives \\
\hline 30. & Sonoma County Energy Independence program: Sonoma County, CA \\
\hline 31. & Home Performance with EnergyStar \\
\hline 32. & ORNL Atlanta, GA project \\
\hline
\end{tabular}

Retrofit initiatives vary in their objectives, approaches, and measures of success (see Table 3). While most of the initiatives focus on completing a set number of retrofits, others focus on an energy savings goal. Most do not fall into the category of "deep" retrofits. Approaches to promote participation most often include community outreach and financing, along with audits and one-stop-shop-style coordination.

Retrofit initiatives explicitly or implicitly make assumptions about factors that motivate homeowners to undertake energy-efficiency modifications of their homes. These assumptions fall into two broad, but not 
Table 2: Retrofit initiatives, by funding source and administration

\begin{tabular}{|c|c|c|c|c|}
\hline \multirow{2}{*}{$\begin{array}{l}\text { Initiative Funding } \\
\text { Source }\end{array}$} & \multicolumn{4}{|c|}{ Initiative Administered By } \\
\hline & Federal & State & Utility & Municipality \\
\hline Federal & 32 & $\begin{array}{l}4^{* *}, 7 \\
12\end{array}$ & 29 & $\begin{array}{l}8,10,13,27, \\
28,31^{* * *}\end{array}$ \\
\hline State & & & & 30 \\
\hline Utility & & & $\begin{array}{l}5,6,15, \\
16,17, \\
18,19, \\
21,22, \\
23,24, \\
25,26\end{array}$ & 14 \\
\hline Municipality & & & $20 *$ & $2,3 *, 9,11$ \\
\hline Private funds & & & & 1 \\
\hline $\begin{array}{ll}\text { Notes: } \\
* \quad \text { Identifies initiatives by } \\
* & \text { Utility is municipal } \\
* * & \text { Initiative is private/pul } \\
* * * & \text { Thirty two separate sta }\end{array}$ & $\begin{array}{l}\text { der; App } \\
\text { deral pa } \\
\text { Iministe }\end{array}$ & $\begin{array}{l}\text { lix A pro } \\
\text { ership } \\
\text { ojects ur }\end{array}$ & associated & b links \\
\hline
\end{tabular}

mutually exclusive, categories. The first category is an economic or financial, and the second is informational.

Economic or financial assumptions tend to view retrofits as investments. Initiatives seeking to entice homeowners from this direction emphasize payback or return on investment and/or such financing mechanisms as low interest loans, repayment through utility bills, and/or financial incentives such as rebates or tax credits. Initiatives emphasizing economic or financial perspectives may conceive of people as economically "rational" actors whose decisions will tilt in the direction of their financial interests (e.g., Case and Guilbault 2012). However, there is increasing evidence that some of these choices actually are "predictably irrational" (borrowing Ariely's 2008 book title). In other words, decisions and behavior are influenced by a host of psychological and social factors (see, e.g., Cialdini 1993, Heath and Heath 2010, Kahneman 2011, Thaler and Sunstein 2009). Indeed, many homeowners do not take advantage of the financial incentives offered for energy-related retrofits.

Another predominant assumption explicitly or implicitly influencing retrofit program design is that information will drive behavior. Initiatives adopting this perspective often include community outreach methods and/or audits to increase homeowner participation. Neighborhood meetings, television and radio ads, and flyers are common outreach methods. Some of these efforts appeal to particular interests or sectors of the population such as "green" consumers ${ }^{2}$. Audits are conducted to different degrees of thoroughness across programs and, from one standpoint, can be viewed simply as an assessment of the condition of the home and opportunities to increase its energy efficiency. But audits also are offered (at varying costs) as an enticement intended to bolster participation, often with the underlying assumption that, once homeowners are presented with a list of energy-related problems at their homes, they will

${ }^{2}$ LeBlanc et al. (2012) show that being "green" is only one of multiple other motivations people have for retrofitting their homes. 
Table 3: Overview of retrofit initiatives, by objective, approach, and measure of success*

\begin{tabular}{|c|c|c|c|c|c|c|c|c|c|}
\hline \multirow[b]{2}{*}{ Primary Objective } & \multicolumn{4}{|c|}{ Primary Approaches } & \multicolumn{5}{|c|}{ Primary Measures of Success } \\
\hline & $\begin{array}{l}\text { Community } \\
\text { Outreach }\end{array}$ & Financing & Audits & $\begin{array}{l}\text { One-Stop- } \\
\text { Shop }\end{array}$ & $\begin{array}{l}\text { Number of } \\
\text { Completed } \\
\text { Retrofits }\end{array}$ & Dollars Saved & $\begin{array}{l}\text { Energy } \\
\text { Saved }\end{array}$ & $\begin{array}{l}\mathrm{CO}^{2} \\
\text { Saved }\end{array}$ & $\begin{array}{l}\text { Number } \\
\text { of New } \\
\text { Laws } \\
\text { Passed }\end{array}$ \\
\hline Energy Savings & $1,2,6,11$ & $2,3,6,11$ & $2,6,11$ & 6,11 & 11 & 3 & $\begin{array}{l}2,3,6, \\
11\end{array}$ & $\begin{array}{l}2,3,6, \\
11\end{array}$ & 1 \\
\hline Number of Retrofits & $\begin{array}{l}4,5,7,8,9 \\
10,12,13 \\
14,15,16, \\
17,18,19 \\
20,21,22 \\
23,24,25 \\
26,27,28 \\
29,30\end{array}$ & $\begin{array}{l}4,5,8, \\
10,12, \\
13,14, \\
15,16, \\
17,18 \\
19,21 \\
22,23, \\
25,26, \\
27,28 \\
29,30 \\
\end{array}$ & $\begin{array}{l}4,8,9 \\
10,13 \\
14,20 \\
27,28 \\
29,30\end{array}$ & 9 & $\begin{array}{l}4,5,7,8,9, \\
10,12,14, \\
15,16,17, \\
18,1920, \\
22,25,26, \\
27,28,29, \\
30\end{array}$ & & $\begin{array}{l}4,8,9, \\
12,13, \\
14,15, \\
16,17, \\
18,19, \\
22,25, \\
26,27, \\
28,29, \\
30\end{array}$ & $\begin{array}{l}4,8,9 \\
13,27 \\
28,30\end{array}$ & \\
\hline Number of "Deep" Retrofits & 31,32 & 31,32 & 31,32 & 31 & 32 & 33 & 31,32 & 31,32 & \\
\hline
\end{tabular}

"Table 1 identifies initiatives by number; Appendix A provides associated web links 
fix those problems ${ }^{3}$. Stated otherwise, the assumption is that information will lead to action....and, perhaps, that people provided with the same information will take the same action. These assumptions are false (e.g., McKenzie-Mohr and Smith 1999). Opinions and actions may be influenced, but not determined, by information.

However, when viewed from a different perspective, audits indeed may spur homeowners to undertake retrofits. It is possible that audits serve as a "foot-in-the-door" (Heath and Heath 2010). Heath and Heath suggest that people are more likely to make a big change if they previously agreed to some smaller change, even if that change is unrelated. Research would be necessary to determine the extent to which the act of agreeing to an audit, itself influences homeowners to undertake retrofits. Likewise, research would be needed to sort out the individual or interactive influences of agreeing to an audit, audit-produced information, and audit-related rebates and other incentives on homeowner decisions (a) to undertake energy-efficiency retrofits and (b) about which measures pursue.

\subsection{The role of homeowners in analyses of residential retrofit initiatives}

Inquiries and analyses involving energy-saving residential retrofits are conducted for multiple purposes and intended for differing audiences. There are many technology-oriented analyses, for example, that focus on such topics as technologies, approaches, or best practices for achieving energy savings, the energy-savings potentials associated with various measures, and/or the cost savings associated with energy conservation measures (e.g., Baechler et al. 2011, Bianchi 2011, Polly et al. 2011, Steven Winter Associates 2010). Products of these analyses often are aimed at practitioners such as designers and builders, and sometimes toward homeowners (e.g., a series of DOE Builders Challenge Technology Information Packages-BC TIPS-for different climate zones ${ }^{4}$; Baechler et al. 2011, Bianchi November 2011, Liaukus 2012, Case et al. 2012). A subset of these efforts emphasize energy savings in the range that would constitute "deep" retrofits and/or whole-house/systems-engineering approaches that view homes as integrated sets of systems (e.g., Amman 2006, Baechler et al. 2011, Bianchi July 2011, Boudreaux et al. April 2012, Boudreaux et al. October 2012, Gordon et al. 2012, McGeough et al. 2012). Like the case studies incorporated into these types of documents, there are numerous case study-style descriptions that emphasize technologies, energy savings, and financial elements in existing homes of differing ages, styles, and conditions in various parts of the country (e.g., Donnelly 2012, Drumheller and Wiehagen 2004, Gordon et al. 2012, Parker et al. 2012, Rowley et al. 2012).

In short, there is much information available to entice or enable homeowners and builders or contractors to conduct energy-saving retrofits. To this end, homeowner or builder/contractor testimonials sometimes are incorporated into documents (e.g., Drumheller and Wiehagen 2004, Ingle et al. 2012). Such testimonials often talk about satisfaction with the process or results, and sometimes about greater comfort and other non-energy, non-financial components of satisfaction. Nevertheless, this large body of literature can be characterized as being about homes, retrofit measures, energy savings, and economics, but not about the homeowners who have to decide whether to retrofit their homes, what measures to install, and how to live with (e.g., use and maintain) retrofit results. Documents targeting homeowners with information about energy saving potential of retrofits are premised upon embedded and false assumptions that homeowners will be motivated to save energy, save money, and 'fix' problems with their homes if only they are made

\footnotetext{
${ }^{3}$ The economic/financial and information assumptions overlap in the sense that cost-benefit calculations and estimated payback periods may be considered to be forms of information.

${ }^{4}$ As examples, hot-humid climate of New Orleans, mixed-humid climate of Atlanta
} 
aware of or provided with sufficient information. And, the information implicitly deemed important is energy, technology, and financially oriented. Information about other so-called nonenergy benefits or impacts, such as comfort, noise, durability or maintenance issues, (Amman 2006, Clendenning et al. 2012, State and Local Energy Efficiency Action Network 2012) is far less prevalent.

An increasing number of studies do focus on homeowners and homeowner behavior (e.g., Brown et al. 2010b, Consortium for Advanced Residential Buildings 2009, Donnelly 2010, EhrhardtMartinez 2010, Parag et al. 2010). Many studies focus on homeowners' responses to different forms of information - billing data, smart meters, and the like (Brown et al. $2010 \mathrm{a}$ and b, Donnelly 2010, Ehrhardt-Martinez 2010, Laitner et al. 2010, Parag et al. 2010, Tiedemann 2010, Vine 2010). Others center on interactions with various technologies, such as programmable thermostats and appliances (Consortium for Advanced Residential Buildings 2009). Still others explore different aspects of changing homeowner or occupants' behaviors (Brown et al. 2010a, Tiedemann 2010, Vine 2010). Relatively few focus on homeowner decision making with regard to energy-saving retrofits of their homes (Brown et al. 2010b, Laitner et al. 2010).

\subsection{A behavioral gap-homeowner decision making}

Missing from these bodies of literature are explorations of homeowner decision making. Thinking about homeowner decision making raises many unanswered, but keenly relevant questions, including the following. Why do homeowners decide to undertake energy-saving retrofits at either traditional or deep levels? Why might they consider, but reject, doing such retrofits? What is the relative importance of energy, non-energy, and financial considerations? How does available information or audit results translate into homeowner actions? What factors influence homeowner decisions about which measures to take, and which to defer or reject?

Systematically raising and answering such questions fills a critical gap in the literature and in practice. Stated crudely, the best and most detailed technical information about how a measure works or how much energy or money it saves does not satisfy or substitute for information about or confidence in contractor skills or familiarity with the technologies, warranty, or maintenance issues (as examples). If homeowner decisions are more oriented toward the latter set of issues than the former, then parties seeking to promote retrofits can develop programs or strategies for addressing them and, in the process, achieve a goal of more energy savings.

This study begins to fill that gap by analyzing the retrofit-related decision making among a group of homeowners. These homeowners volunteered to participate in a technical study of wholehouse, deep retrofits. That is, they volunteered to participate in a study hoping to achieve $30-50 \%$ energy savings. Homeowners signed on to that research project knowing that they would pay for all retrofit measures, with estimated expenditures in the range of tens of thousands of dollars. These factors make this group of homeowners unusual. Nevertheless, understanding the decisions of this group of homeowners can reveal insights useful to expand the reach of retrofit initiatives across America, whether those retrofits are traditional, deep (whole-house), or targeted. It is important to reiterate that this report focuses on homeowner decision making when homeowners actually are making decisions about which measures to install and footing the bill for those choices. We exclude from consideration retrofit efforts aimed at low-income homes, where the homeowners or occupants pay little or nothing for the measures installed. 


\section{OVERVIEW OF PROJECT}

This exploratory effort aimed to gain insights that could help the U.S. Department of Energy and utilities extend the reach of retrofit programs, particularly those designed to strive for deep energy savings (30-50\%). It did so by focusing on homeowner perspectives, investigating their deep-retrofit-related decisions and experiences. Both because of the small size of our sample and the exploratory nature of our inquiries, we analyzed results qualitatively to gain insights about the kinds of considerations that homeowners bring to bear in deciding about whether, or what, retrofit-related actions to take. Statistical analyses of central tendencies or averages_-particularly among such a small sample — would not have achieved those goals.

The homeowners in this study were associated with homes selected as part of a separate technical study designed to achieve 30-50\% household energy savings (Boudreaux et al. 2012; Boudreaux, Biswas, and Jackson 2012). The energy savings were to be accomplished by (1) taking a wholehouse approach to assessing potential savings, (2) making comprehensive recommendations to homeowners on the technological measures they could take to achieve those savings, and (3) measuring and monitoring baseline and post-retrofit results. Each home in the study was selected to be typical of existing houses in the area that were old enough to need renovation. Homes were selected from a set of approximately 120 homes, partly so as to be similar to a collection of unoccupied research houses (Campbell Creek Research Houses) in the vicinity in which occupancy was simulated. A component of the technical deep retrofit project sought to determine whether the same types of houses with actual occupants could achieve comparable energy savings through retrofits. Ultimately, the houses ranged in age from 15 to 109 years and from 1,800 square feet to 4,400 square feet in size. Table 4 summarizes descriptive details about each home.

As part of the technical research project, the houses first received multiple energy audits. An auditor accredited by the Tennessee Valley Authority (TVA) inspected each home for a few hours and produced a series of recommendations for lowering energy use. Then an ORNL research team consisting of building researchers and an independent HERS rater spent approximately a day at each house. They performed diagnostic measurements including blower door and duct blaster tests and inspected basements, crawlspaces, and attic areas. These measurements and one year of pre-retrofit energy usage records from utility bills ${ }^{5}$ then were used to create two separate energy models of each house, one a calibrated baseline energy model and the other a revision of the baseline model with the recommended energy efficiency measures applied. These data were compiled into a detailed report that outlined each home's energy usage and recommended a suite of retrofit measures that would maximize energy savings, showing estimates of how much energy could be saved if the recommended package of measures would be installed. The ORNL retrofit team stayed involved throughout the installation process, even conducting blower door testing to

\footnotetext{
${ }^{5}$ In a few cases where the homes had not been inhabited for the prior year, these billing data did not exist.
} 
Table 4: Details of retrofit homes

\begin{tabular}{|c|c|c|c|c|c|c|}
\hline Home & $\begin{array}{l}\text { Year } \\
\text { Built }\end{array}$ & $\begin{array}{c}\text { Square } \\
\text { Footage } \\
\left(\mathrm{ft}^{2}\right)\end{array}$ & Stories & Foundation & $\begin{array}{l}\text { Pre-retrofit } \\
\text { HERS Rating }\end{array}$ & $\begin{array}{c}\text { Yearly } \\
\text { Utility } \\
\text { Cost }\end{array}$ \\
\hline Baker & 1966 & 5120 & 2 & $\begin{array}{l}\text { Unfinished conditioned } \\
\text { basement }\end{array}$ & 119 & $\$ 2,500$ \\
\hline Capital & 1993 & 2438 & 2 & Vented crawlspace & 115 & $\$ 1,751$ \\
\hline Celebration & 1978 & 2884 & 1 & Vented crawlspace & 123 & $\begin{array}{c}\$ 1,425 \\
\text { (7 } \\
\text { months } \\
\text { of utility } \\
\text { usage) }\end{array}$ \\
\hline Country & 1970 & 2448 & 1 & $\begin{array}{l}\text { Finished conditioned } \\
\text { basement/vented } \\
\text { crawlspace }\end{array}$ & 100 & $\$ 1,700$ \\
\hline Eagle Bend & 1938 & 4273 & 2 & $\begin{array}{c}\text { Conditioned } \\
\text { basement/vented } \\
\text { crawlspace }\end{array}$ & 169 & $\$ 3,504$ \\
\hline Gaiter & 1940 & 1769 & 2 & $\begin{array}{l}\text { Unconditioned } \\
\text { basement }\end{array}$ & 259 & N/A \\
\hline Green & 1909 & 2295 & 2 & $\begin{array}{c}\text { Unconditioned } \\
\text { Basement/Crawlspace }\end{array}$ & 186 & N/A \\
\hline Oasis & 1966 & 1800 & 1 & Vented crawlspace & 127 & $\$ 2,295$ \\
\hline Old Tavern & 1977 & 3766 & 2 & Vented Crawlspace & 133 & $\$ 4,317$ \\
\hline Scenic & 1966 & 4328 & 2 & $\begin{array}{c}\text { Finished } \\
\text { basement/crawlspace }\end{array}$ & 135 & $\$ 3,580$ \\
\hline Summit & 1995 & 3110 & 2 & $\begin{array}{c}\text { Unfinished conditioned } \\
\text { basement }\end{array}$ & 119 & $\$ 2,223$ \\
\hline
\end{tabular}

direct air sealing efforts and insulation installation at some homes. The team also installed sensors in those homes that followed the recommendations most closely, to monitor the post-retrofit energy usage for two years to access the performance of the energy efficiency measures. Participating homeowners learned about the project in a variety of ways-from newspaper articles, presentations, and friends or colleagues. Their participation in the retrofit project was voluntary. And, as a condition of their participation, homeowners knew they would be responsible for paying for the retrofit. They knew that these costs could be significant-potentially tens of thousands of dollars. Most of the homes enrolled in the study were owned by the people who lived in the subject houses or, in one case, intended to live in the house. One house was owned by a national park, and one house was owned by a historic preservation organization that, as planned, sold the remodeled home to a private owner. Our sample did not include 
builders or other parties who own and work on homes for flipping or speculation purposes. Just as the houses selected for the technical project were diverse, so were the backgrounds of the homeowners. Professionally, the homeowners range from a psychologist to a bishop to engineers. About half were married and about half had children living at home.

Our study elicited homeowner perspectives through a series of interviews with the homeowners. In the case of the house first owned by the historic preservation organization, we initially interviewed the president of the organization and subsequently interviewed the new homeowner. We designed our study around a series of three interviews with the retrofit homeowners. Our intent was to conduct the first interview shortly after homeowners received recommendations for which measures to install. The rationale was that this juncture in time would enable us to learn why people participated in the technical retrofit project and to capture homeowners' considerations in deciding which recommendations to follow in as close to real time as possible. Our research design included a second interview, to occur during or shortly after the installation of the retrofit measures. This timing was intended to tap homeowner thoughts about the retrofit process-how it affected daily life, the degree to which it met or exceeded expectations, etc. - while those recollections were fresh. The third, and final interview was designed to occur approximately one year after the retrofit was completed. This timing of this interview would allow homeowners to experience life in a retrofitted house and formulate impressions of how the newly installed technologies were performing and whether household members' behavior had changed as a consequence of the retrofits. We developed semi-structured interview protocols to guide each discussion with homeowners (see Appendix B). These interview protocols structured the topics to be addressed during each interview, but allowed for variation in the phrasing and ordering of questions as well as the ability to follow lines of inquiry in response to topics raised by interviewees.

While we endeavored to adhere to our research design, the practicalities of coordinating with the homeowners and with the technical research team thwarted our efforts. We actually ended up conducting one or two interviews instead of the desired three interviews with homeowners. In some cases, occasionally due to the quickness with which homeowners began implementing recommendations, the first and second interviews were combined. In other cases, only one interview was conducted. Most often, two researchers conducted each interview and took handwritten notes of interviewees' responses. Our research design was vetted and approved by the Oak Ridge Site-Wide Institutional Review Board. As per that approval, interviewees provided their 'informed consent' to participate. That is, they were given a sheet that briefly described the study, the benefits to interviewees, the voluntary nature of their participation, and the confidentiality of their responses. 
(THIS PAGE LEFT BLANK INTENTIONALLY) 


\section{FINDINGS}

The group of homeowners that were the subject of this study are alike in their willingness to participate in a technical research project, their desire to seek deep energy savings in their existing homes, and their willingness to expend substantial monetary sums in the process. Yet, we found a remarkable degree of variation even in this small group. This diversity is exemplified by the fact that, even within this group of highly motivated homeowners, some chose not to implement any of the recommendations. We group the participants into three categories, those who implemented all recommendations, in one case going far beyond the initial suggestions; some of the recommendations; and none of the recommendations. We use these distinctions to describe homeowners' varying perspectives.

\subsection{Homeowners who implemented all recommended measures}

Homeowners at five of the eleven study houses implemented all the recommendations (see Appendix $\mathrm{C}$ for fact sheets on each of these homes). These five homeowners upgraded insulation and sealed the building envelope. They upgraded HVAC systems and hot water heaters, and they upgraded lighting to $100 \%$ CFL or LED. At two homes, solar photovoltaics were recommended. One homeowner installed the recommended system, while the other exceeded the recommended $2.5 \mathrm{~kW}$ system with an $8.5 \mathrm{~kW}$.

The reasons for participation varied across the houses. Two homeowners already were planning renovations and decided that retrofitting fit their project goals. Two of the homeowners said that the project goals were consistent with their personal goals-one homeowner mentioned the desire to live a "greener" lifestyle, while another wanted to be a model home for energy efficiency. One homeowner stated that he felt it was the "patriotic duty" of all citizens to make their homes more energy efficient. All of these homeowners mentioned access to unbiased expertise as a major motivation for their participation, while some also cited the ORNL affiliation and the involvement of a specific ORNL staff member as major factors. The access to expertise also raised the homeowners' expectations from their retrofits. The historic preservation organization expected that experts would help choose the right technologies for the house. All five of these homeowners expected to achieve increased energy efficiency and energy savings.

Homeowners in these five households indicated that their experiences with the auditors and experts were positive. Homeowners were generally pleased with the recommendations they received, particularly the more thorough ORNL research team recommendations. Homeowners were happy to have the experts' help in selecting measures to install. Interactions with contractors, however, were mixed. Three homeowners reported negative experiences with contractors. These negative experiences ranged from wildly divergent cost estimates, to cleanup, to inaccurate settings on equipment. In one case, a homeowner who was very pleased with a sealing process implemented by one contractor said that a different crew from the same company did a poor job in implementing that same sealing technology in a different portion of his home. One homeowner, a single mother, was particularly grateful to have had access to an expert (an ORNL researcher) to coordinate work with the contractors and assure that the quality of the work was excellent. Despite their experiences with installation, all homeowners were pleased with the results. All of the homes had noticeable energy savings and improved comfort. None of the homeowners reported behavior changes among household members as a result of the retrofit. Some explicitly stated that they wanted to continue with familiar behaviors, such as preferred 
temperature settings. Homeowners mentioned lights being left on; programmable thermostats at three of the houses were not used.

Four of the homeowners offered advice for other homeowners considering a retrofit. All four suggested researching contractors for the retrofit and finding someone with a good reputation. Two homeowners suggested working in small steps and tackling any issues that arise when they are found; one homeowner even suggested adding $20 \%$ to the project budget for any unforeseen problems. One homeowner had no advice for other homeowners, but suggested that government agencies promote retrofit programs since retrofits meet most agencies’ mission statements.

\subsection{Homeowners who implemented some measures}

Three homeowners installed some of the recommended measures. Two of these homeowners mentioned finances as the reason for only installing some measures as opposed to all. When funds are constrained, homeowners have to make decisions about which measures to install. But, the ways in which they make those decisions vary. One homeowner spent nearly $\$ 20,000$ on selected measures and simply could not afford more work at that time, and the other homeowner was concerned with return on investment, unsure how long the family would live in the home. The third homeowners completed the measures until they thought they had satisfied their goals and met their needs. For some homeowners, there appeared to be an informal cost-benefit calculus that influenced their decisions. While some interviewees developed their own spreadsheets, others expressed a more

Table 5: Measures installed, by type

\begin{tabular}{|l|l|c|}
\hline \multirow{4}{*}{$\begin{array}{l}\text { Component } \\
\text { of home }\end{array}$} & Measures & $\begin{array}{l}\text { Number of } \\
\text { households } \\
\text { that installed } \\
\text { measure }\end{array}$ \\
\hline \multirow{2}{*}{$\begin{array}{l}\text { Building } \\
\text { envelope }\end{array}$} & $\begin{array}{l}\text { Air seal } \\
\text { Insulate } \\
\text { crawlspace }\end{array}$ & $\begin{array}{l}\text { Insulate } \\
\text { attic }\end{array}$ \\
\cline { 2 - 3 } & $\begin{array}{l}\text { Insulate } \\
\text { walls }\end{array}$ & 3 \\
\hline \multirow{2}{*}{$\begin{array}{l}\text { Mechanical } \\
\text { systems }\end{array}$} & \begin{tabular}{l} 
New HVAC \\
\cline { 2 - 3 }
\end{tabular} & $\begin{array}{l}\text { New hot } \\
\text { water }\end{array}$ \\
\hline \multirow{2}{*}{$\begin{array}{l}\text { Appliances } \\
\text { and lighting }\end{array}$} & $\begin{array}{l}\text { Upgrade } \\
\text { lighting }\end{array}$ & $\begin{array}{l}\text { New } \\
\text { appliances }\end{array}$ \\
\cline { 2 - 3 } & & 1 \\
\hline
\end{tabular}

casual calculation that recommended measures were or were not "worth" pursuing. In some cases, these judgments were mediated homeowner experiences or judgments about the current status of their home or equipment. An example is one homeowner who described her basement as the least drafty room in the house declined to insulate basement walls.

The particular measures installed at each house varied, depending partly on the household goals. Table 5 details the measures installed at these three houses by type and whole-house component system. All these homeowners air sealed and insulated the crawlspace. Two homeowners insulated the attic and upgraded lighting. One of the homeowners bought a new HVAC system, though because of cost he chose not to install the geothermal system recommended, choosing instead a cheaper system rated more efficient than their existing unit. Another homeowner upgraded the hot water heater to a tankless system, after doing his own research and deciding it was more appropriate than the electric heat pump water heater system recommended. The 
research that homeowners did on their own indicates how engaged some of them were in the decision-making process.

One homeowner chose to participate because the family was planning renovations already and decided that a retrofit worked with their existing plans. Another homeowner chose to participate because he was concerned with indoor air quality (IAQ) and thought air sealing and insulation could improve the quality of his home. The third homeowner chose to participate because they wanted expert advice in deciding which measures to install. Two of the homeowners expected to gain knowledge through their participation in the program, and the other homeowner expected increased comfort in the house.

Two homeowners were pleased with their experiences during the project. They thought the recommendations they received were thorough, and they had no complaints with contractors. The third homeowner was confused by the recommendations and felt apprehensive about contacting experts. This homeowner chose only to air seal and insulate the crawlspace, but was pleased with those results. Both noticed increased energy efficiency, and the homeowner concerned with IAQ noticed an improvement in the air quality.

All homeowners in this category suggested that other homeowners considering retrofits should carefully research the recommended measures. One homeowner emphasized the need to consider the source of information and to be wary of anyone who does not perform diagnostics. Another homeowner suggests being prepared for "sticker shock" of what measures cost.

\subsection{Homeowners who implemented no measures}

Three of the homeowners chose to implement none of the recommended measures. The reasoning behind these choices varied. One home is part of a national park complex, with limited government funding each year to maintain all their buildings. This project had a lower priority than others that could benefit from capital expenditures. But the interviewee indicated a hope that involvement with the technical retrofit project could be used to attract funding, particularly if the resulting retrofitted home could be used for educational purposes within the park. Another homeowner received eight separate bids from contractors and could not agree with any contractor on pricing. The homeowner decided that he would rather do nothing than pay prices that he thought were unfair, particularly when there was uncertainty about how effective some of the recommended measures may be. The third homeowner chose to do nothing yet. These homeowners are incorporating the retrofit into a larger renovation project. They have spent years carefully outlining the minutiae of preserving the historical integrity of their home and plan to retrofit the home when the overall plan is complete.

These homeowners expected the retrofits to achieve increased energy efficiency. All three sets of homeowners were pleased with their interactions with auditors and experts and with the recommendations they received. The national park property manager offered no advice. The other homeowners suggested carefully researching contractors, with one homeowner saying that the markup of costs is substantial, so "be prepared for your jaw to drop."

\subsection{Why did homeowners take action?}

This group of homeowners illustrates the point that multiple motivations_-and not any particular single motivation—underlie decisions to undertake deep home retrofits. Saving energy clearly 
was among these motivations. All homeowners were partly motivated by a desire to improve their home's energy profile. Lower utility bills sometimes motivated homeowners; in other cases homeowners explicitly said either that they were not interested in payback periods or that they would never expect to see a return on their investments by way of lower utility bills. These motivations frequently are assumed to drive homeowner behavior (see section 2), but they fail to incorporate an array of other motivations expressed by interviewees including patriotic duty, comfort, health, being more "green," and serving as an example for others.

These homeowners' experiences indicate that it may be important to distinguish motivations or desires from catalysts for action. While motivations can inspire homeowners to take action, they do not necessarily determine the outcomes. Of particular note in this regard are those homeowners who were undertaking major remodeling activities in their homes. One homeowner was undertaking what amounted to a whole-house remodeling activity. Another had a sagging roof over a portion of his home and had to undertake major structural repairs. Two homeowners essentially gutted their historic homes - in one case partially as a result of envelope insulation decisions emanating from the technical retrofit project. This group of homeowners was distinctive in that they portrayed even sizeable investments in energy-saving retrofits as relatively minor costs in much more expensive and expansive remodeling efforts. The same financial outlay may be seen entirely differently when viewed from the standpoint of a marginal additional cost versus as a standalone investment. This same kind of perceptual and choice-making difference may apply to related aspects of energy-saving home retrofits like 'disruption'. It would take additional empirical inquiry to determine how these sorts of differences affect resulting decisions

The technical retrofit project itself was a catalyst for homeowners, particularly with regard to access to and guidance from an unbiased, well-respected expert. Homeowners across all groups mentioned access to a retrofit expert as a reason to take action. Access to an expert seemed to boost homeowner confidence in their projects and seemed to lead to homeowner satisfaction with the results.

Interviewees demonstrated that people who have same motivations sometimes make markedly different decisions. The clearest example of this point is the variation in homeowners' choices with regard to implementing the technical recommendations. As another example, historic preservation motivated one homeowner to implement all the suggested measures and another to postpone implementing any of the measures. Homeowners' decisions regarding which retrofit to implement also were affected by pre-existing remodeling plans, desired comfort levels, and indoor air quality.

\subsection{Why did some homeowners not take action?}

Despite being highly motivated and interested in their recommendations, some homeowners still did nothing. In one case, lack of funding prevented any retrofit work, but the other two cases were different. One homeowner took his recommendations to contractors and sought bids, but was unsuccessful in choosing someone to start the work. The other homeowners took the recommendations and incorporated them into their long-range plans for the home.

These homeowners demonstrate that information, alone, will not lead to near-term homeowner action. Participants in the technical research project were provided with detailed information. Yet, some homeowners needed something extra before taking action. In one case, it was help with contractors; in another, it was more time to plan. The information provided by experts did not always satisfy homeowner needs. One homeowner chose to install only one measure—crawlspace 
insulation. The homeowner did not think that the recommendations were sufficient to help him decide which contractor recommendation to follow. In this case, the homeowner needed a more guidance on implementing the recommendations.

\subsection{What were the homeowners' experiences in implementing recommendations?}

Homeowner interactions with contractors varied across houses. Contractors came with a set of common practices, and level of training and interest in creating an energy-efficient project seemed to play a part in their effectiveness. One homeowner said he had to personally train the contracted crew on how to install insulation correctly. However, another homeowner expressed his satisfaction with the interactions between the ORNL team and the insulation contractors at his house. All three groups of homeowners considered the contractors' costs to be high. However, homeowners across the three groups expressed satisfaction with the process, despite how many measures they installed. Those who installed some of the recommended measures cited increased comfort and energy efficiency as pleasant results of the retrofits.

\subsection{What do the homeowners advise?}

Homeowners across the three groups of houses suggested that other homeowners carefully investigate the contractors in their area to find the best crews for the job and to know whom to avoid. They also mentioned researching the recommended measures, so as to have a better idea of what to expect from the retrofit process and to better understand what is being done to the house. Advice for contractors was mainly limited to gaining knowledge in energy efficiency and seeking certifications to distinguish themselves from other contractors. Homeowners found it difficult to know which contractors are knowledgeable. The main homeowner advice for utilities and government agencies was to endorse retrofit programs. Homeowners across the three groups of houses mentioned that a utility endorsement would give credibility to a retrofit program. One homeowner mentioned that government agencies would benefit from endorsing retrofit programs, since retrofit programs align with many of their mission statements. 
(THIS PAGE LEFT BLANK INTENTIONALLY) 


\section{DISCUSSION}

There is no single definition of a deep home retrofit. Building experts suggest a range of energy savings from 30-75\%. From homeowners' perspectives, it is not clear whether a "deep" home retrofit is a part of a continuum of measures that people can implement or a distinctive class of retrofits. The whole-house, integrated systems approach to retrofitting seemed to resonate with homeowners. Nevertheless, homeowners' choices did not always align with the sequence of steps implied by an envelope-mechanical systems-interior elements approach.

It is clear that even homeowners interested in saving energy and willing to invest substantial sums to retrofit their homes make different choices. They are motivated by many factors beyond energy and economics. All homeowners involved in this project mentioned access to an unbiased expert as important to their decisions. Trust is an important element-homeowners need to trust both the expertise and that the individual is not biased (i.e., has nothing to gain as a consequence of his or her advice). Such a trusted expert may be key to project success. He or she can spur homeowner action; help homeowners to navigate tough, confusing, and sometimes conflicting choices; and convey to homeowners (and contractors) what constitutes "quality" workmanship. The lack of access to such trusted expertise by homeowners can cause inaction. The role of unbiased retrofit experts in the market is currently vacant, though a manual or website could possibly provide insight for homeowners to feel comfortable making retrofit-related choices. But such resource material should go beyond the provision of information. Instead, it should help homeowners to make choices about what to do with that information and it should help homeowners know such things as what questions to ask, what to expect during a retrofit, and how to know if the work is done properly.

Homeowners said that local contractors need more training in energy efficiency and its application to common building practices. Inconsistencies in recommendations, price estimates, and sometimes performance underscored this perspective. Certification may be one approach that provides homeowners with greater confidence. However, the homeowners in this study needed to select contractors from a utility-provided list to be able to benefit from utility-provided incentives.

Some homeowners involved in this project already were considering renovations when deciding to pursue energy-saving retrofits. Homeowners engaged in remodeling efforts may approach energy-saving retrofits from an entirely different perspective from those who are not. The former group may frame energy-saving measures as marginal costs-small financial outlays relative to much greater renovation or remodeling costs. This while we're remodeling, we may as well make it energy-efficient mentality seems markedly different from one where energy-saving retrofits are standalone projects that require sometimes large sums of money. It therefore may be useful to use the existing renovation market to promote deep retrofits, focusing on the marginal costs of retrofit compared to the costs of renovation. If homeowners see that retrofitting will not cost them that much more, they may be more likely to implement retrofit measures. Considering this context when marketing different retrofit initiatives may be valuable.

Homeowners also frequently mentioned non-energy benefits such as comfort, patriotism, and being "green," as major motivations for retrofit. Marketing efforts should not be focused only on energy savings or dollar savings. Appealing to an array of consumer interests may increase consumer interest in retrofits and increase the number of completed retrofit projects. 
The interviewed homeowners clearly stated that their retrofit projects did not result in any significant behavior change. Performing a retrofit does not guarantee homeowner behavior change related to energy efficiency. Homeowners need further training/guidance on how to maximize efficiency through behavior. Retrofit programs could accomplish this through workshops or other forms of community outreach.

This study, with its small sample of homeowners, provided useful insights into the perspectives of homeowners undertaking a deep home retrofit. It would be useful to conduct a similar study with a larger sample of homeowners, collecting data from a large enough sample to be statistically valid.

Contractors are the ground force behind retrofits. They are the faces homeowners see inside their homes, and they are praised or blamed for the quality of work performed. A study with a large sample of contractors to learn their attitudes, beliefs, and knowledge of energy efficiency could be useful for learning whether the contracting force needs further education on energy efficient building practices.

Currently, DOE and others are promoting a whole-house integrated systems approach to energysaving retrofits. Perhaps there also should be a whole-retrofit integrated systems approach that incorporates the network of parties necessary to decide, install, maintain, and use retrofit measures. 


\section{REFERENCES}

Amman, J. "Valuation of Non-Energy Benefits to Determine Cost-Effectiveness of Whole-House Retrofits Programs: A Literature Review.” 2006. American Council for an Energy-Efficient Economy.

Ariely, D. Predictably Irrational: The Hidden Forces that Shape our Decisions. 2008. New York: HarperCollins.

Baechler, M. C., T. L. Gibride, M. G. Hefty, P. C. Cole, and P. M. Love. Builders Challenge Guide to 40\% Whole-House Energy Savings in the Cold and Very Cold Climates. Volume 12, Building America Best Practices Series. PNNL-20139.

(http://apps1.eere.energy.gov/buildings/publications/pdfs/building_america/cold_climate_guide_ 40percent.pdf) February 2011.

Bianchi, M. "Challenges and Opportunities to Achieve 50\% Energy Savings in Homes: National Laboratory White Papers.” July 2011. NREL. Building America Program, U.S. Department of Energy.

Bianchi, M.V.A. Technical Barriers, Gaps, and Opportunities Related to Home Energy Upgrade Market Delivery. National Renewable Energy Laboratory. November 2011.

Boudreaux, P., Biswas, K. and Jackson, R. Advancing Residential Retrofits in the Mixed-humid Climate to Achieve Deep Energy Savings: Final Report on Knoxville, TN Homes. ORNL/TM2012/533. October 2012 (updated January 2013).

Boudreaux, P., Hendrick, T., Christian, J., Jackson, R. Deep Residential Retrofits in East Tennessee. ORNL/TM-2012/109. Oak Ridge National Laboratory. April 2012.

Brown, M., Chandler, J., Lapsa, M. “Adding a Behavioral Dimension to Utility Policies that Promote Residential Efficiency.” People-Centered Initiatives for Increasing Energy Savings. 2010a. American Council for an Energy-Efficient Economy.

Brown, M., Chandler, J., Lapsa, M., Ally, M. “Adding a Behavioral Dimension to Residential Construction and Retrofit Policies.” People-Centered Initiatives for Increasing Energy Savings. 2010b. American Council for an Energy-Efficient Economy.

Case, S., Ferington, D., Smith, D., Studdard, A. "Scaling Up Retrofit Programs through Web Software Tools and HPXML.” ACEEE Summer Study 2012.

Case, S. and Guilbault, K. “Using Social Psychology to Drive Deep Energy Retrofits.” 2012 ACEEE Summer Study.

Cialdini, R. B. Influence: The Psychology of Persuasion. 1993. Collins Business Essentials.

Clendenning, G., Browne, C., Hoefgen, L., Prahl, R., Cohen, M., Azulay, G. "Measuring Participant Perspective Non-Energy Impacts (NEIs).” 2012 ACEEE Summer Study on Energy Efficiency in Buildings. 
Consortium for Advanced Residential Buildings. "What's Wrong With My Home?” 2009. Steven Winter Associates, Inc. www.carb-swa.com.

De La Chapa, C., Case, S., and Ellis, C. "New Marketing and Engagement Strategies for Residential Efficiency Programs.” ACEEE Summer Study 2012.

Donnelly, K. “The Technological and Human Dimensions of Residential Feedback: An Introduction to the 13-1 Broad Range of Today's Feedback Strategies.” People-Centered Initiatives for Increasing Energy Savings. 2010. American Council for an Energy-Efficient Economy.

Drumheller, S. C. and J. Wiehagen. Strategies for Energy Efficient Remodeling: SEER 2003 Case Study Report, February 27, 2003-October 31, 2004. NREL/SR-550-36474. National Renewable Energy Laboratory, NAHB Research Center. November 2004.

Ehrhardt-Martinez, K. “Inside the Black Box: Household Response to Feedback.” PeopleCentered Initiatives for Increasing Energy Savings. 2010. American Council for an EnergyEfficient Economy.

Granade, H. C., Creyts, J., Derkach, A., Farese, P., Nyquist, S., and Ostrowski, K. "Unlocking Energy Efficiency in the U.S. Economy.” McKinsey Global Energy and Materials. July 2009.

Gordon, A., Howard, L., Kunkle, R., Lubliner, M., Auer, D., Clegg Z. "Newporter Apartments: Deep Energy Multifamily Retrofit Short-Term Results.” 2012. BA-PIRC. Building America Program, U.S. Department of Energy.

Heath, C. and Heath, D. Switch: How to Change Things When Change is Hard. 2010. New York: Random House.

Ingle, A., Moezzi, M., Lutzenhiser, L., and Diamond, R. "How Well Do Home Energy Audits Serve the Homeowner?” 2012 ACEEE Summer Study.

Jackson, R., Boudreaux, P., Kim, E., and Roberts, S. “Advancing Residential Energy Retrofits.” 2012 ACEEE Summer Study.

Kahneman, D. Thinking Fast and Slow. 2011. New York: Farrar, Strauss and Giroux.

Laitner, J., Ehrhardt-Martinez, K., "Examining the Scale of the Behavior Energy Efficiency Continuum.” People-Centered Initiatives for Increasing Energy Savings. 2010. American Council for an Energy-Efficient Economy.

LeBlanc, W., Cooper, R., and Reeves, A. “Who Wants Efficiency? Americans' Attitudes and Actions Around Energy Use.” 2012 ACEEE Summer Study.

Leiserowitz, A., Maibach, E., Roser-Renouf, C. Saving Energy at Home and On the Road: A Survey of Americans' Energy Saving Behaviors, Intentions, Motivations, and Barriers. Yale Project on Climate Change. 2009. 
Liaukus, C. “Communication of Energy Efficiency Information to Remodelers: Lessons From Current Practice.” 2012. NREL. Building America Retrofit Alliance. Building America Program, U.S. Department of Energy.

Mackres, E., Alschuler, E., Stitely, A., Brandt, E. “The Role of Local Governments and Community Organizations as Energy Efficiency Implementation Partners: Case Studies and a Review of Trends.” American Council for an Energy Efficient Economy. February 2012.

Martel, J.C.; "A Review of Residential Retrofit Programs Offered by Utilities in the Southwest.” National Renewable Energy Laboratory. August 2011.

McGeough, U., Baker, W., Peters, J., Beitel, A. "Survey of Whole House Programs in Midwestern Climates.” 2012. Partnership for Advanced Residential Retrofit. Building America Program, U.S. Department of Energy.

McKenzie-Mohr, D., and W. Smith. 1999. Fostering Sustainable Behavior. British Columbia, Canada: New Society Publishers.

Middle Class Task Force, Council on Environmental Quality, Executive Office of the President. Recovery Through Retrofit. October 2009.

Parag, Y., Strickland, D. "Personal Carbon Budgets: Helping Individuals to Live in a Carbon Constrained World.” People-Centered Initiatives for Increasing Energy Savings. 2010. American Council for an Energy-Efficient Economy.

Parker, D., Sherwin, J. “Achieving Very High Efficiency and Net Zero Energy in an Existing Home in a Hot-Humid Climate: Long-Term Utility and Monitoring Data.” 2012. NREL. Building America Program, U.S. Department of Energy.

Polly, B., Gestwick, M., Bianchi, M., Anderson, R., Horowitz, S., Christensen, C., Judkoff, R. “A Method for Determining Optimal Residential Energy Efficiency Retrofit Packages.” 2011. NREL. Building America Program, U.S. Department of Energy.

Rowley, P., Kerr, R., Brand, L. "Evaluation of Northern Illinois Residential Retrofit Delivery Practices.” 2012. NREL. Building America Program, U.S. Department of Energy.

State and Local Energy Efficiency Action Network. 2012. Energy Efficiency Program Impact Evaluation guide. Prepared by Steven R. Schiller, Schiller Consulting Inc., www.seeaction.energy.gov.

Steven Winter Associates, Inc. "Retrofitting America: A 1970s Home Energy Efficiency Analysis.” 2010. Consortium for Advanced Residential Buildings (CARB). Building America Program.

Sweatman, P. and Managan, K. "Financing Energy Efficiency Building Retrofits: International Policy and Business Model Review and Regulatory Alternatives for Spain.” 2010. Climate Strategy and Partners. www.climatestrategy.es/index.php?id=19.

Thaler, R. H., and Sunstein, C. R. Nudge: Improving Decisions about Health, Wealth, and Happiness. 2009. New York: Penguin Books. 
Tiedemann, K. "Behavioral Change Strategies That Work: A Review and Analysis of Field Experiments 21-1 Targeting Residential Energy Use Behavior.” People-Centered Initiatives for Increasing Energy Savings. 2010. American Council for an Energy-Efficient Economy.

Tonn, B., Hawkins, B., Eisenberg, J., Schweitzer, M. Process Evaluation of the Home Performance with Energy Star Program. Oak Ridge National Laboratory. June 20, 2012.

Vine, E. "A Conceptual Framework for Integrating Behavior and Behavioral Change in the Energy 19-1 Efficiency Program Cycle.” People-Centered Initiatives for Increasing Energy Savings. 2010. American Council for an Energy-Efficient Economy.

Walker, I., Fisher, J., and Less, B. “Deep Energy Retrofit Performance Metric Comparison: Eight California Case Studies.” Lawrence Berkeley National Laboratory. ACEEE 2012 Summer Study. 


\section{Appendix A: Retrofit Initiatives and Links}

1. Green Codes Task Force: New York, NY

http://www.nyc.gov/html/gbee/html/codes/proposals.shtml

2. Residential Energy Conservation Ordinance (RECO): Berkely, CA

http://www.ci.berkeley.ca.us/reco/

3. Energy Conservation Audit and Disclosure (ECAD) Ordinance: Austin, TX

http://www.austinenergy.com/about\%20us/environmental\%20initiatives/ordinance/index.htm

4. Clean Energy Works Portland: Portland, OR

http://www.cleanenergyworksoregon.org/

5. Community Mobilization Initiative: New Bedford, MA

http://www.marioninstitute.org/programs/green-jobs-green-economy-initiative/communitymobilization-initiative-pilot-program

6. Marshfield Energy Challenge: Marshfield, MA

http://www.marshfieldenergy.org/nstar.html

7. Colorado Retrofit Ramp-Up program: Boulder County, CO

http://www.colorado.gov/cs/Satellite/OIT-2/OIT2/1249907621143

8. Green Retrofit Initiative: San Antonio, TX

http://www.sanantonio.gov/oep/SustainabilityPlan.asp?res=1600\&ver=true

9. Greenworks Philadelphia: Philadelphia, PA

http://www.phila.gov/green/greenworks/

10. Better Buildings Greensboro: Greensboro, NC

http://www.greensboro-nc.gov/index.aspx?page $=2940$

11. Long Island Green Homes program: Babylon, NY

http://ligreenhomes.com/

12. State Energy Program

http://www1.eere.energy.gov/wip/sep.html

13. EnergyWorks KC: Kansas City, MO

http://www.kcmo.org/CKCMO/Depts/CityManagersOffice/OfficeofEnvironmentalQuality/E nergyWorksKC/index.htm

14. Palm Desert Energy Partnership Set to Save program: Palm Desert, CA

http://www.cityofpalmdesert.org/Index.aspx?page=484

15. CPS Energy Savers program: San Antonio, TX

http://www.cpsenergysavers.com/

16. Arizona Public Service Company retrofit program http://www.aps.com/main/green/choice/choice_20.html 
17. Salt River Project

https://www.srpnet.com/Default.aspx

18. Tucson Electric Power: Tucson, AZ

https://www.tep.com/efficiency/reports/\#

19. Xcel Energy Company retrofit program: CO

http://www.xcelenergy.com/

20. Fort Collins Utilities retrofit program: Fort Collins, CO

http://m.fcgov.com/utilities/residential/conserve/rebates-programs

21. Southwestern Public Service Company: New Mexico http://xcelenergy.com/staticfiles/xe/Regulatory/Regulatory\%20PDFs/NM-DSM/NM-DSM2012-Energy-Efficiency-and-Load-Management.pdf

22. New Mexico Gas Company retrofit program https://www.nmgco.com/Residential_Insulation_Rebate

23. Nevada Power Company retrofit program https://www.nvenergy.com/home/saveenergy/

24. Sierra Pacific Power Company retrofit program: NV https://www.nvenergy.com/home/saveenergy/

25. Rocky Mountain Power Company wattsmart energy efficiency program: UT http://www.rockymountainpower.net/env/epi.html

26. Questar Gas Company Thermwise program: Utah http://www.thermwise.com/home/Audit.html

27. Energy Impact Illinois Residential Retrofit Program: Chicago and Rockford, IL http://energyimpactillinois.org/

28. Flagstaff Residential Energy Retrofit Program: Flagstaff, AZ http://flagstaff.az.gov/index.aspx?nid=1630

29. TVA Energy Right program http://www.energyright.com/residential/

30. Sonoma County Energy Independence program: Sonoma County, CA http://www.sonomacountyenergy.org/

31. Home Performance with EnergyStar http://www.energystar.gov/index.cfm?fuseaction=hpwes_profiles.showSplash

32. ORNL Atlanta, GA project Jackson, Roderick; Boudreaux, Philip; Kim, Eyu-Jin; and Roberts, Sidney. “Advancing Residential Energy Retrofits.” 2012 ACEEE Summer Study. 


\section{Appendix B: Interview Protocols}

\section{Primary Interview Script, Homeowners of Retrofitted Homes}

Introduction: Hello, I'm Amy Wolfe and this is Tim Hendrick. We work in the Environmental Sciences Division at ORNL, and want to talk with you today about your participation in the extreme home retrofit program. Specifically, we want to elicit your feedback on:

1. How you heard about the retrofit program

2. Why you chose to participate

3. Your expectations

4. Your communications with others

5. Your home's recommendations

6. Your retrofit-related choices

7. Your advice for others

Our goals are to gain a better understanding of the decision-making processes that go into a home retrofit and how homeowners respond to those changes, as well as how to improve the home retrofit process and expand programs like this one to more homes and communities. This interview is voluntary, and you may choose to end it at any time.

So, let's talk about each of these issues separately. [NOTE: Bold questions are main prompts; regular text denotes prompts or follow-on questions.]

Question 1: How did you hear about this program?

- What first attracted you to it?

Question 2: What convinced you to participate in this program?

- What is your main motivation? (possible prompts: energy efficiency, technology, demonstrating leadership, saving money down the road, increased comfort, better re-sale value, "free advice," etc.)

- What were your major considerations about participating in the program?

- What pushed you toward [or away] from the program?

- Did you consult with anyone before making your final decision? Who?

Question 3: What are your expectations from the retrofit [process; outcomes]?

- Main positive expectations?

- Any negative expectations?

Question 4: To what extent have you discussed your retrofit plans [or this program]?

- With family?

- Neighbors?

- Friends?

- Co-workers? 


\section{Question 5: What were your impressions of the recommendations you received?}

- In what order did you receive your recommendations? [TVA,ORNL]

- How useful were the recommendations you received?

- What would have made them more useful?

Question 6: Why did you choose these (give them a sheet highlighting their selections from the full list of recommendations) measures? [Alternative, if homeowners have not yet made choices...giving homeowners a sheet with the full list of recommendations for their home: What is your current thinking about which retrofit measures you will select?]

- Which measures are you implementing?

o Yourself?

o Via contractors?

o In what sequence?

- Why? To what extent was this decision influenced by the sequence suggested in the audits?

- (if they choose not to adopt some recommendation) Why did you decide against [the specific measure(s)]?

- Possible follow-ups: To what extent did [up-front cost; financing; bang-for-the buck; potential household disruption; fixed vs. active (that homeowner had to deal with) measures; familiar vs. unproven technologies; aesthetics; etc] affect your decision?

- Were there conflicting recommendations? (If yes, ask who they chose to follow and why)

Question 7: What advice do you have for other homeowners who may be considering a retrofit?

- For utilities like TVA?

- For governmental and non-governmental organizations wishing to promote deep home retrofits [in general and in neighborhoods]?

- For contractors who may be installing the measures? 


\section{Secondary Interview Script, Homeowners of Retrofitted Homes}

Introduction: Hello once again. I'm Amy Wolfe and this is Tim Hendrick. We want to talk with you again today about the retrofit process happening in your home. Specifically, we want to find out about:

1. The status of your project

2. The installation process

3. Any differences the retrofits have made

4. Advice you may have for other homeowners

Our goal is to gain a better understanding of the retrofit process, how it affects homeowners, and how it may be improved.

Let's talk further about each of these issues.

Item 1: What is the status of your project? (give them the sheet from the first interview with their recommendations and discuss each item)

Item 2: Describe the overall installation process [For $3^{\text {rd }}$ interview, inquire about installation of any measures in the time period between interviews]

- Possible prompts - length of time, effectiveness/reliability of contractors, extent of disruption, costs, or "surprises"?

- To what extent did/has the installation process met your expectations? To what extent did/has the installation process not met your expectations?

o Smoothest aspects? Biggest frustrations?

o To what extent did you deviate from your original retrofit plan [refer to sheet from first interview]? If deviation, why?

- What advice do you have for other homeowners facing similar retrofit installation processes?

- What advice do you have for contractors conducting these sorts of retrofits [to make the process more marketable for the contractors; more appealing to homeowners]?

\section{Item 3: How have the retrofits worked?}

- To what extent have they met your expectations [possible prompts: energy efficiency, technology, demonstrating leadership, saving money down the road, increased comfort, better re-sale value, "free advice," and with regard to costs, operation, and maintenance]?

- What, if any, benefits arose that you did not anticipate?

- What, if any, negative effects arose that you did not anticipate?

- To what extent have the retrofits changed your [and household members'] behavior?

o Possible prompts: check meters [and, what do you do after you check meters]; set thermostats or other equipment differently; clean/change filters more often; use different filters; etc.]

o To what extent have the retrofits changed how you maintain your home [and equipment]?

o To what extent have the retrofits affected your behavior in other ways [e.g., outside your home-water usage; how/what you drive; behavior at work; etc.] 
o To what extent have you communicated about the retrofits with others [family, friends, neighbors, co-workers...]?

- Have you undertaken any further retrofit work beyond the recommendations? (if yes, what? If no, do you plan to in the near term?)

Item 4: Advice [in addition to questions associated with Item 2]: Based on your experiences with the retrofits to date, what advice do you have for other homeowners who may be considering a retrofit?

- Looking back, what would you do differently?

- Advice for utilities like TVA?

- Advice for governmental and non-governmental organizations wishing to promote deep home retrofits [in general, and in neighborhoods]? 


\section{Third Interview Script, Homeowners of Retrofitted Homes}

Introduction: Hello again. I'm Amy Wolfe and this is Tim Hendrick. We want to talk with you today about life in your home after the retrofit was completed. Specifically, we want to know about:

1. Your responses to the new systems installed

2. Changes to your daily life

3. Advice you may have for others

Our goal is to gain understanding of how homeowners adjust to life in a retrofitted home and analyze how that process may be simplified in the future, making retrofits more marketable.

Let's talk more about each of these issues.

\section{Issue 1: Responses to installed systems}

- What were your expectations of life after the retrofit?

- To what extent has the retrofit met your expectations?

- What levels of energy savings have you noticed?

- How well are the new systems performing?

- To what extent are you using the systems in the manner you were instructed?

\section{Issue 2: Changes to daily life}

- What changes in routine have been caused by the retrofit? (ask about positive and negative changes)

- Has living in a retrofitted home caused you to modify your life in other ways?

- Have you done any work beyond the initial recommendations? (if yes, what? If no, do you plan to?)

- To what extent have you discussed life in the retrofitted house with friends?

- Family?

- Neighbors?

- Co-workers?

Issue 3: Advice for others

- How can the process of adjusting to life in a retrofitted home be simplified for other homeowners?

- Would the endorsement of a utility provider or municipal government have affected your decision to perform a retrofit?

- To what extent should retrofits be performed in your neighborhood? 
(THIS PAGE LEFT BLANK INTENTIONALLY) 


\section{Appendix C: Fact Sheets}

The project team drafted fact sheets for homes involved in this study that were intended to span technicaland homeowner-related aspects of deep home retrofit experiences. As work proceeded, this effort was merged with a related activity to develop fact sheets. The resulting five fact sheets are attached in this appendix. 


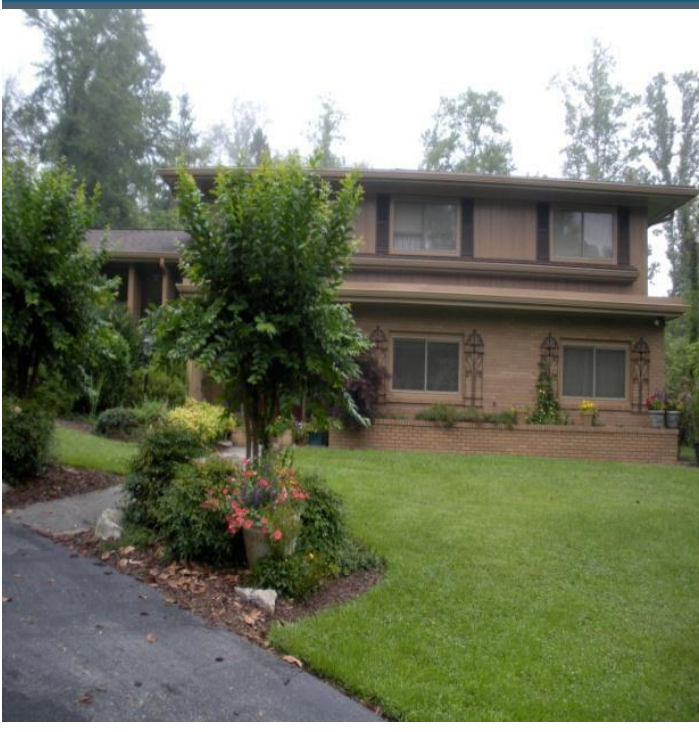

\section{PROJECT INFORMATION}

Construction: Deep Energy Retrofit

Type: Single-family

Size: 5,210 $\mathrm{ft}^{2}$

Research Partners: TVA, Owens

Corning, Bruce Granville

Retrofit Package Costs: $\$ 14,929$

Date completed: 2012

Climate Zone: Mixed humid

\section{PERFORMANCE DATA}

\section{HERS index:}

Pre-retrofit: 119

Post-retrofit: 75

Annual energy cost savings: $\$ 230$

Measured whole house source energy savings: $21 \mathrm{MMBtu}(8 \%)$

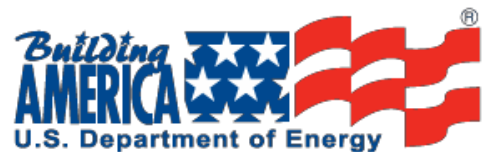

Building America

Efficient Solutions for Existing Homes

\section{Case Study:}

Deep Energy Retrofits in East Tennessee - Baker

\author{
Knoxville, TN
}

The residential sector used $22 \%$ of the nation's energy in 2010. The Department of Energy's Building America program has a research goal of demonstrating market-ready energy retrofit packages that reduce home energy use by $30-50 \%$. Oak Ridge National Laboratory (ORNL) contributed to this research goal by spurring and analyzing five residential retrofits in the mixed humid climate around Knoxville, TN. In addition to the Building America goal, ORNL set out to understand why homeowners decide to do retrofits, how much do whole house retrofits actually save and if the retrofits are cost effective.

The owner of the Baker home voluntarily participated in the project with the goal of increasing the energy efficiency of the home along with increasing the comfort of the home during the winter seasons. The Baker home was built in 1966 . It is a two story, $5210 \mathrm{ft}^{2}$ single-family home with 6 bedrooms, 3 full bathrooms and 2 half bathrooms. Prior to the retrofit, ORNL audited the home with various research partners and provided recommendations to the homeowners for retrofit measures. The lessons learned from this deep energy retrofit will help inform future retrofit construction and research.

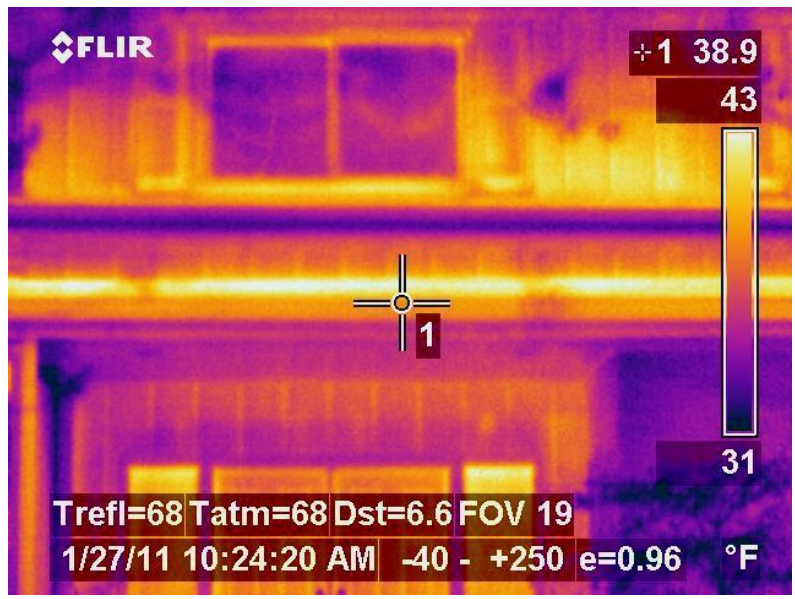

The lack of a pressure and thermal barrier between the soffit and space between the first and second floors cause heat loss from the front soffits as seen in the image above. 


\section{KEY ENERGY-EFFICIENCY MEASURES}

\section{HVAC:}

- 4-ton 16 SEER 9.5 HSPF heat pump with gas backup, Supply ducts replaced in basement and sealed with mastic in all other places.

\section{Envelope:}

- First floor band joist: R-9

- Attic Floor: R-38, Attic knee wall: R19, First floor flat attic: R-30

- Doors weather stripped and sealed; replaced garage and basement doors

- Windows: air sealed with caulk

\section{Lighting, Appliances, and Water Heating:}

- Electric heat pump water heater (2.4 EF)

For more Information, please visit: www.buildings.energy.gov

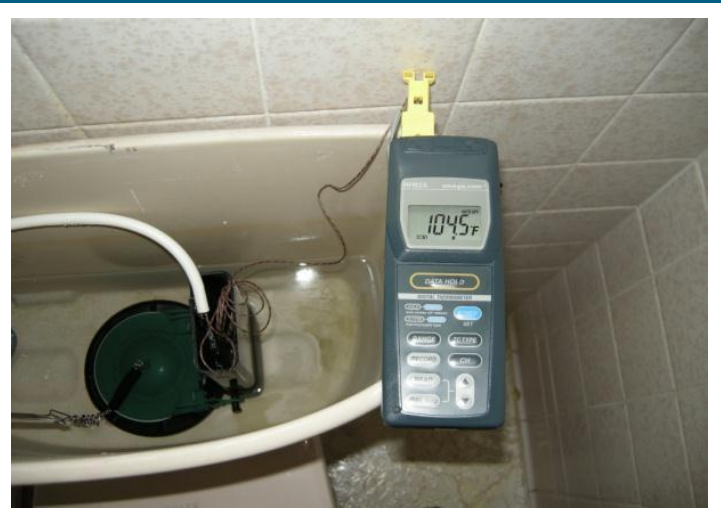

Why is the toilet bowl filling with $105^{\circ} \mathrm{F}$ water? Because a hot water recirculation pump used the main cold water line as a return to the water heater tank.

\section{Lessons Learned}

- A centrally located heat pump water heater, installed in the conditioned basement, replaced a gas water heater located in the garage at the far end of the home. This retrofit had many benefits, including a more efficient water heater, less distribution loss due to the more centralized location, less tank loss in the winter due to being in the conditioned basement, and dehumidification due to the heat pump water heater reducing the load of the stand-alone dehumidifier in the basement. During the heating season, this retrofit saved $25 \%$ in source energy over the gas water heater.

- The HVAC contractor told the homeowner to keep the HVAC fan on continuously during the summer months to keep the air mixed and a more consistent temperature throughout the home. This increased the daily electricity use by about $19 \mathrm{kWh}$ /day during the summer, or about $\$ 56$ per summer month.

- The Baker home saved $8 \%$ source energy and $32 \%$ site energy due to the retrofit. The homeowner switched from a gas-hydronic backup heating system, which was used often, to a more efficient electric heat pump. The homeowner also switched from a gas water heater to electric heat pump water heater. Switching such a large amount of gas energy consumption to electric energy affects the source energy savings in a negative way, since electric energy has a conversion factor about three times as large as gas when converting to source energy.

- To provide instant hot water at the point of use, a recirculation pump was initially in the home. However, because the main cold water line was used as a return line to the water heater, it also contained recirculated hot water. This caused cold water draws, like a toilet flush, to be warm (see photo above where the toilet water is measured at $\left.105^{\circ} \mathrm{F}\right)$. The cold water that refilled the cold water line was then circulated back to the water heater. So flushing the toilet sometimes was enough to trigger the gas water heater to turn on!

"It is important to carefully choose a subcontractor. It is also just as important to become educated on what a retrofit entails." - Homeowner 


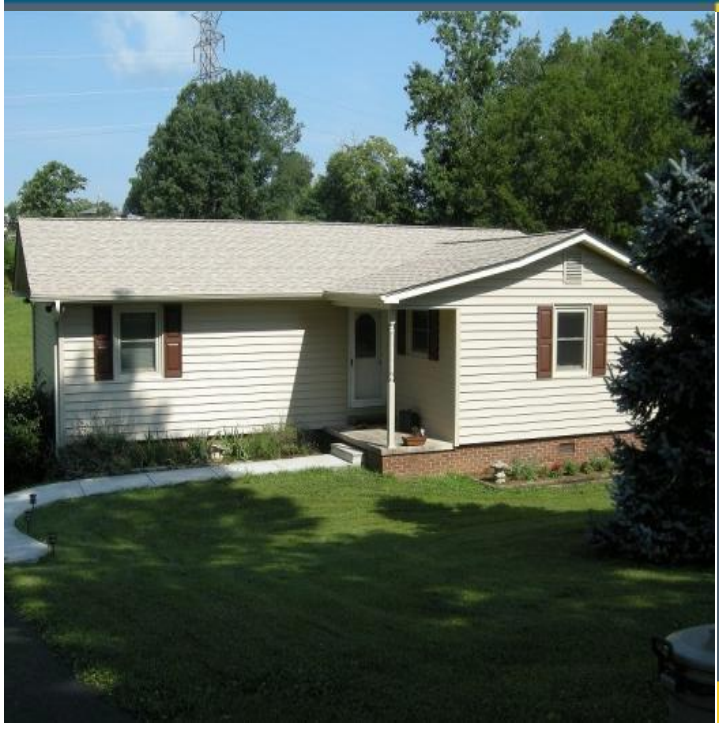

\section{PROJECT INFORMATION}

\section{Construction: Deep Energy Retrofit}

Type: Single-family

Size: $2,448 \mathrm{ft}^{2}$

Research Partners: TVA, Owens

Corning, Bruce Granville

Retrofit Package Costs: $\$ 23,835$

Date completed: 2012

Climate Zone: Mixed humid

\section{PERFORMANCE DATA}

\section{HERS index:}

Pre-retrofit: 100

Post-retrofit: 66

Annual energy cost savings: $\$ 648$

Whole house source energy savings: $74 \mathrm{MMBtu}(33 \%)$

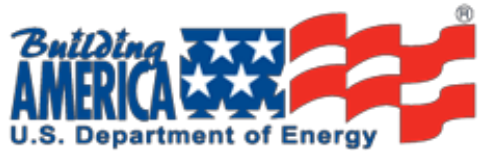

Building America

Efficient Solutions for Existing Homes

Case Study:

Deep Energy Retrofits in East Tennessee - Country

\author{
Knoxville, TN
}

The residential sector used 22\% of the nation's energy in 2010.

The Department of Energy's Building America program has a research goal of demonstrating market-ready energy retrofit packages that reduce home energy use by $30-50 \%$. Oak Ridge National Laboratory (ORNL) contributed to this research goal by spurring and analyzing five residential retrofits in the mixed humid climate around Knoxville, TN. In addition to the Building America goal, ORNL set out to understand why homeowners decide to do retrofits, how much do whole house retrofits actually save and if the retrofits are cost effective.

The owner of the Country home voluntarily participated in the project with the goal of increasing the energy efficiency of the home. The Country home was built in 1970s. It is a one story, 2,448 $\mathrm{ft}^{2}$ singlefamily home with 4 bedrooms and 2 bathrooms. Prior to the retrofit ORNL audited the home with various research partners and provided recommendations to the home owners for retrofit measures. The lessons learned from this deep energy retrofit will help inform future retrofit construction and research.

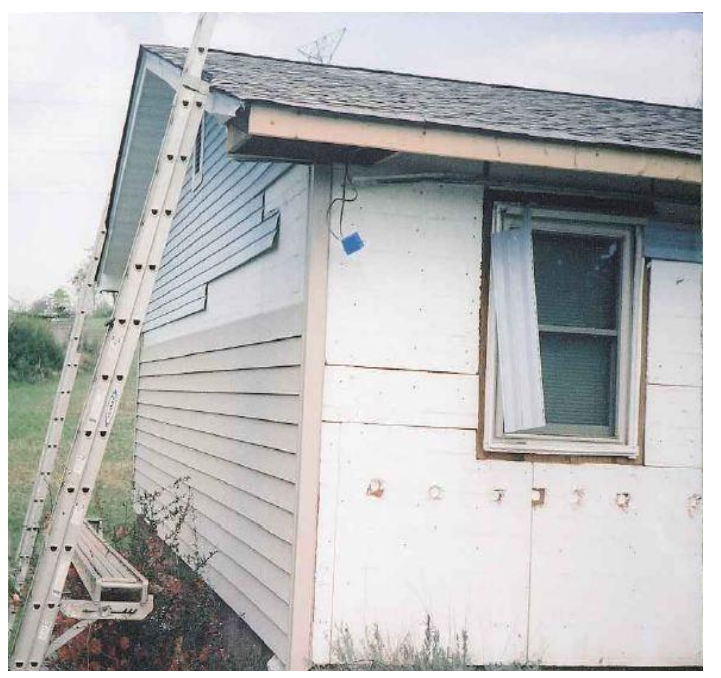

Holes can be seen in the exposed wall were the foam was injected into the wall space via a "drill and fill" procedure. 


\section{KEY ENERGY-EFFICIENCY MEASURES}

\section{HVAC:}

- A split unit with 3-ton capacity and an efficiency of 19 SEER and 9 HSPF.

- New unit replaced a package unit so the compressor stayed outside but the air handler with associated ductwork was relocated inside the conditioned basement.

\section{Envelope:}

- Basement band joist: R-16; Crawlspace band joist: R-22

- Kitchen walls: R-16, other exterior walls: R-14, Exterior wall insulating sheathing: R-9

- Air infiltration was reduced by $42 \%$ from 8.6 $\mathrm{ACH}_{50}$ to $5.0 \mathrm{ACH}_{50}$

\section{Lighting, Appliances,} and Water Heating:

- $96 \%$ of lighting was changed to CFLs

- Water heater: 2.4 EF electric heat pump water heater was installed

For more Information, please visit: www.buildings.energy.gov
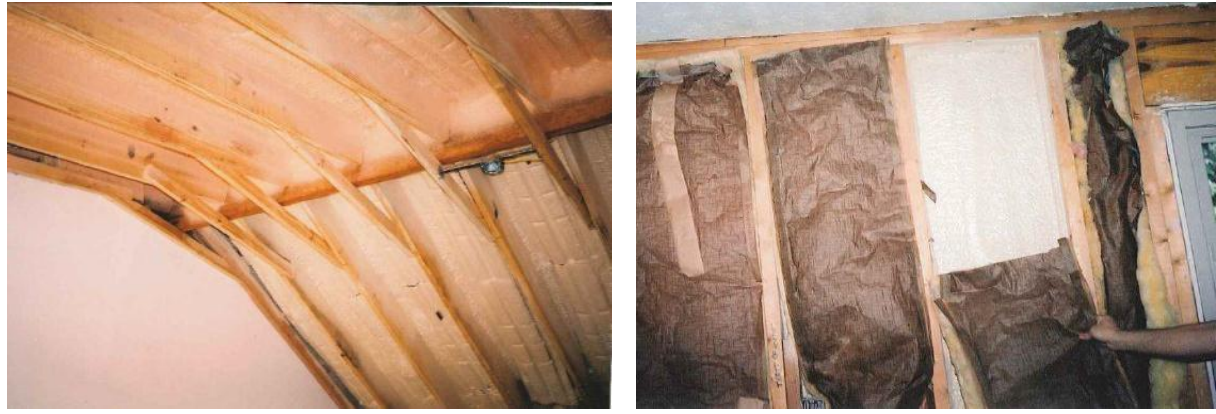

Spray foam insulation on the living room cathedral ceiling (left photo) and the kitchen walls (right photo).

\section{Lessons Learned}

- Comfort and flexibility is a major concern for homeowners completing energy retrofits. The Country homeowner chose a larger capacity HVAC system than was recommended, mainly because the homeowner thought it would ensure comfort and allow for greater space conditioning flexibility.

- Remodeling or major home repair are excellent opportunities to employ energy retrofits with minimal extra cost and inconvenience. The homeowner began the energy retrofit in conjunction with extensive roof repair.

- The package HVAC unit was replaced with a split unit (see pictures below), which enabled the air handler to be placed inside the conditioned basement. This contributed to a decrease in duct leakage from 23 to $7 \%$.
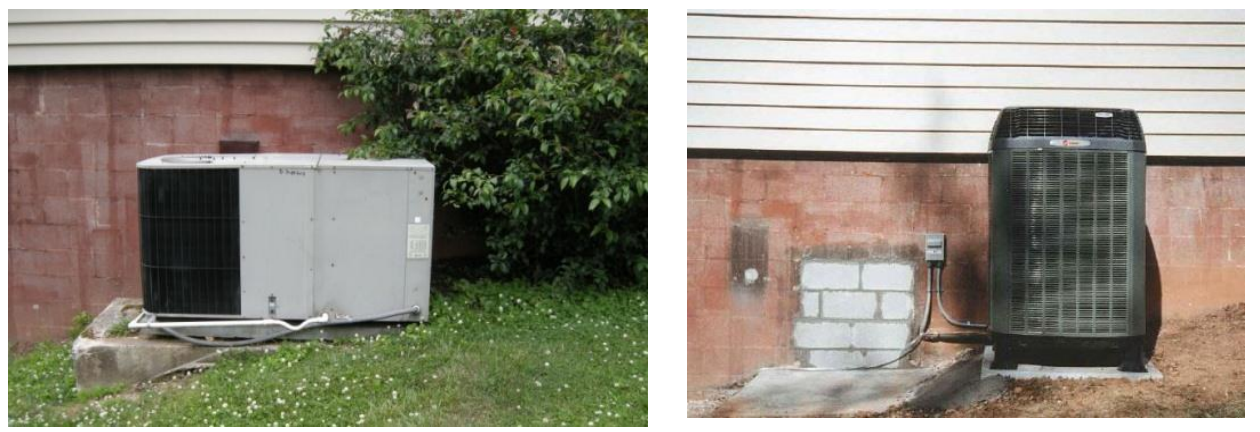

- The baseload energy needed to provide routine household needs such as appliances, electronics and lighting was reduced by over $25 \%$ due to energy star refrigerator, heat pump water heater, and efficient lighting retrofits.
The U.S. Department of Energy's Buildi ng America program is engineering the American home for energy performance, durability, quality, affordability, and comfort. 


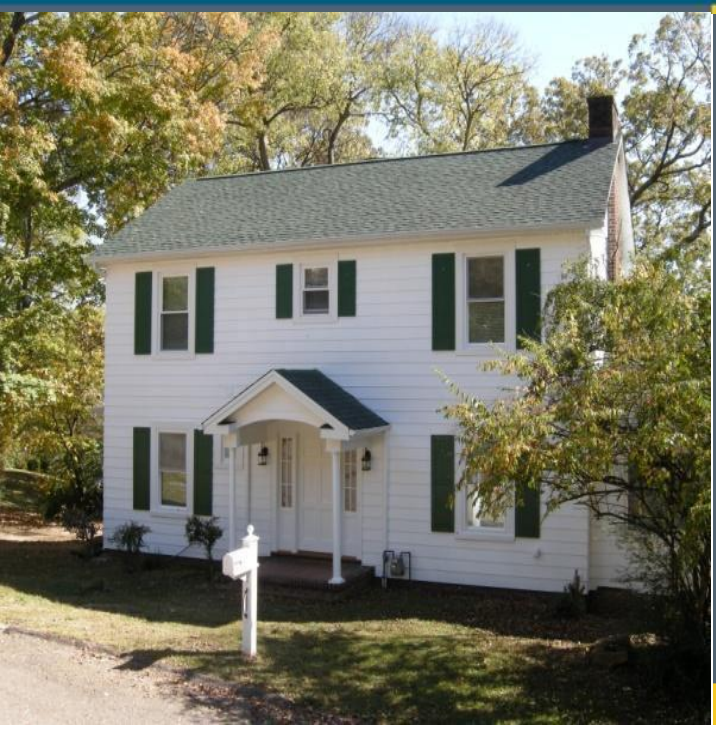

\section{PROJECT INFORMATION}

Construction: Deep Energy Retrofit

Type: Single-family

Size: $1,769 \mathrm{ft}^{2}$

Research Partners: TVA, Owens

Corning, Bruce Granville

Retrofit Package Costs: $\$ 39,699$

Date completed: 2012

Climate Zone: Mixed humid

\section{PERFORMANCE DATA}

HERS index:

Pre-retrofit: 259

Post-retrofit: 75

Annual energy cost savings: $\$ 1,700$

Whole house source energy savings: $179 \mathrm{MMBtu}(70 \%)$
Building America

Efficient Solutions for Existing Homes

\section{Case Study:}

Deep Energy Retrofits in East Tennessee - Gaiter

\author{
Knoxville, TN
}

The residential sector used $22 \%$ of the nation's energy in 2010. The Department of Energy's Building America program has a research goal of demonstrating market-ready energy retrofit packages that reduce home energy use by 30-50\%. Oak Ridge National Laboratory (ORNL) contributed to this research goal by spurring and analyzing five residential retrofits in the mixed humid climate around Knoxville, TN. In addition to the Building America goal, ORNL set out to understand why homeowners decide to do retrofits, how much do whole house retrofits actually save and if the retrofits are cost effective.

The owners of the Gaiter home voluntarily participated in the project with the goal of renovating the home and updating it to local code. However, it was determined that these goals required gutting the home. As a result the homeowners decided to also install energy efficient measures. The Gaiter home was built in the 1940's. It is a two story, $1,769 \mathrm{ft}^{2}$ single-family home with 3 bedrooms and 2 bathrooms. Prior to the retrofit ORNL audited the home with various research partners and provided recommendations to the home owners for retrofit measures. The lessons learned from this deep energy retrofit will help inform future retrofit construction and research.

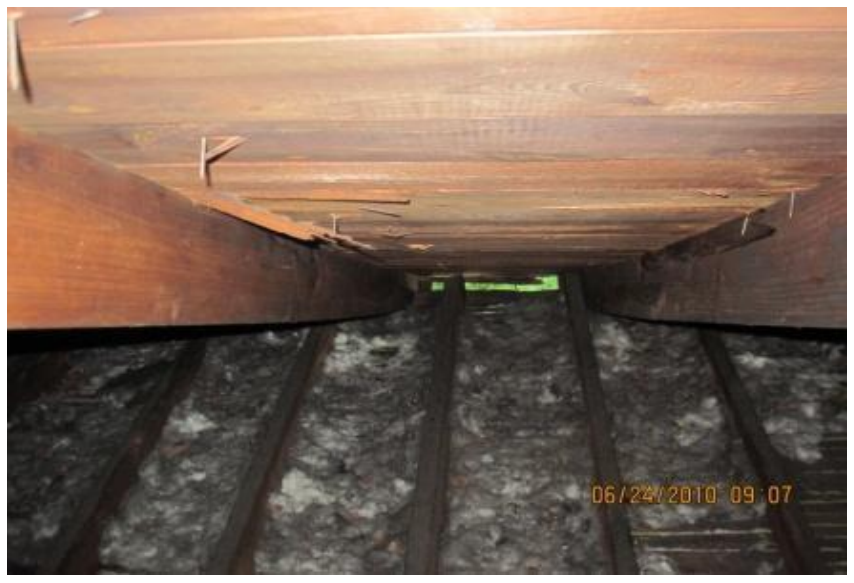

Sparse attic insulation before the retrofit 


\section{KEY ENERGY-EFFICIENCY MEASURES}

\section{HVAC:}

- A high-efficiency 3-ton capacity unit with 18 SEER rating and $9.5 \mathrm{HSPF}$

- All new ducts were installed and sealed with liquid mastic

\section{Envelope:}

- Attic volume was sealed from the exterior with 1" of closed cell foam plus 8" of open cell foam on the roof deck resulting in $\mathrm{R}-34$.

- Exterior walls : R-16

- Band joist in basement: R-6

\section{Lighting, Appliances, and Water Heating:}

- Lighting: 90\% CFLs

- Water Heating: electric heat pump water heater with a $2.4 \mathrm{EF}$ rating

For more Information, please visit: www.buildings.energy.gov

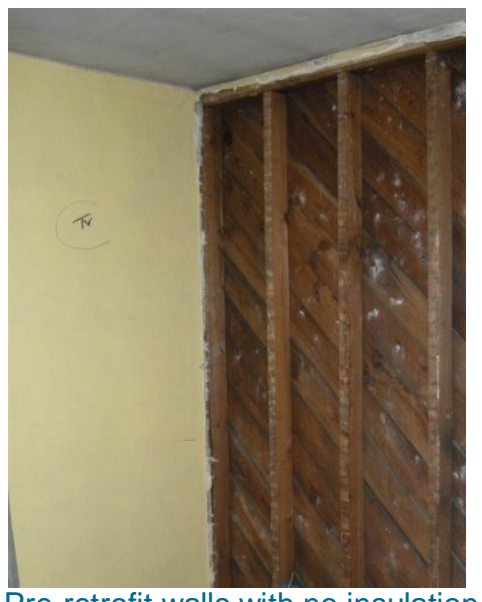

Pre-retrofit walls with no insulation

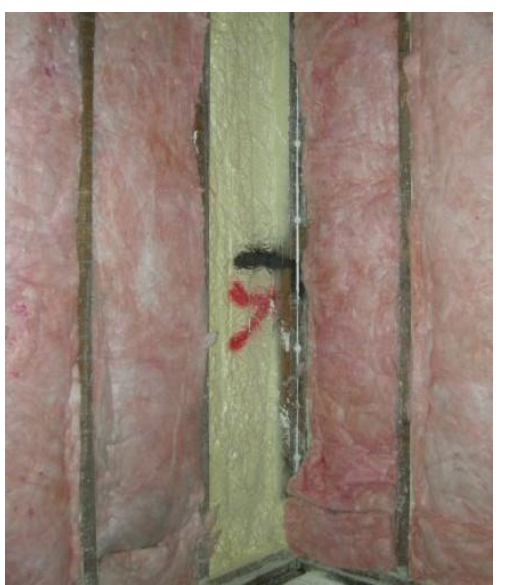

Post-retrofit wall with flash and batt

\section{Lessons Learned}

- Remodeling or major home repair are excellent opportunities to employ energy retrofits with minimal extra cost and inconvenience. The homeowner began the energy retrofit in conjunction with bringing the home up to code which required removing all the drywall to rewire the home.

- The temperature in the sealed attic was within $7^{\circ} \mathrm{F}$ of the second floor temperature throughout the year. Because the ducts are located in the attic, energy losses via the ducts are minimized.

- One inch of closed cell spray foam was applied on all above grade walls, the band joist between the first and second floor, and around windows. These measures reduced the air infiltration in the home by $28 \%$.

- The retrofit of a $70+$ year old home can save over $50 \%$ source energy.

"Retrofits make your house stronger. However, in the process, it is important to be engaged with who you are working with and actively discuss the project."

- Homeowner
The U.S. Department of Energy's Building America program is engineering the American home for energy performance, durability, quality, affordability, and comfort. 


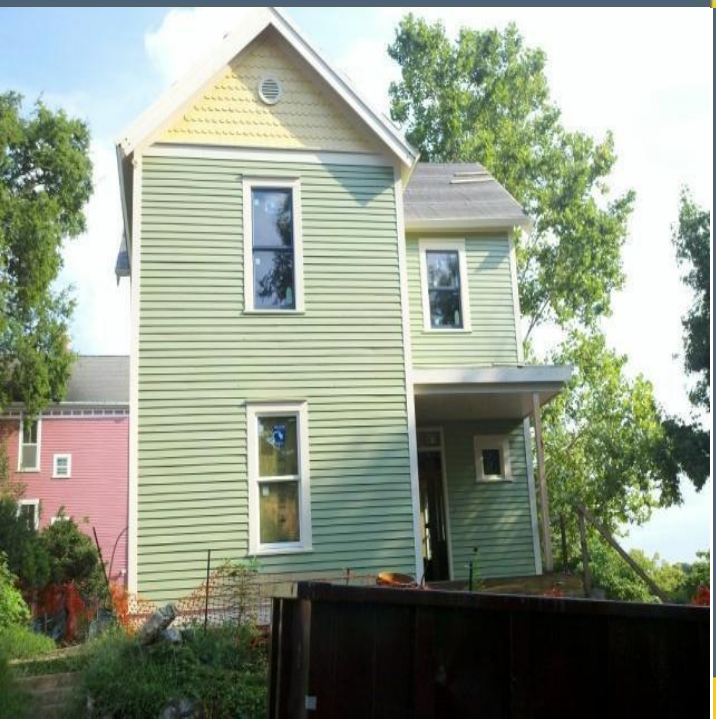

\section{PROJECT INFORMATION}

Construction: Deep Energy Retrofit

Type: Single-family

Size: $2,295 \mathrm{ft}^{2}$

Research Partners: TVA, Owens

Corning, Bruce Granville

Retrofit Package Costs: $\$ 45,462$

Date completed: 2012

Climate Zone: Mixed humid

\section{PERFORMANCE DATA}

HERS index:

Pre-retrofit: 186

Post-retrofit: 61 (w/ PV), 67 (w/o

PV)

Annual energy cost savings:

$\$ 1,458$

Whole house source energy savings: $154 \mathrm{MMBtu}(58 \%)$

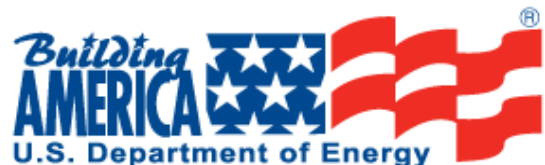

Building America

Efficient Solutions for Existing Homes

\section{Case Study:}

Deep Energy Retrofits in East

Tennessee - Green

\author{
Knoxville, TN
}

The residential sector used $22 \%$ of the nation's energy in 2010. The

Department of Energy's Building America program has a research goal of demonstrating market-ready energy retrofit packages that reduce home energy use by $30-50 \%$. Oak Ridge National Laboratory (ORNL) contributed to this research goal by spurring and analyzing five residential retrofits in the mixed humid climate around Knoxville, TN. In addition to the Building America goal, ORNL set out to understand why homeowners decide to do retrofits, how much do whole house retrofits actually save and if the retrofits are cost effective.

The Green home is owned by a historic preservation organization. The organization voluntarily participated in the project with the goal of increasing the energy efficiency of the home for resale. The Green home was built in 1909. It is a two story, 2,295 sq. ft. single-family home with 3 bedrooms and 2 and a half bathrooms. Prior to the retrofit ORNL audited the home with various research partners and provided recommendations to the preservation organization for retrofit measures. The lessons learned from this deep energy retrofit will help inform future retrofit construction and research.

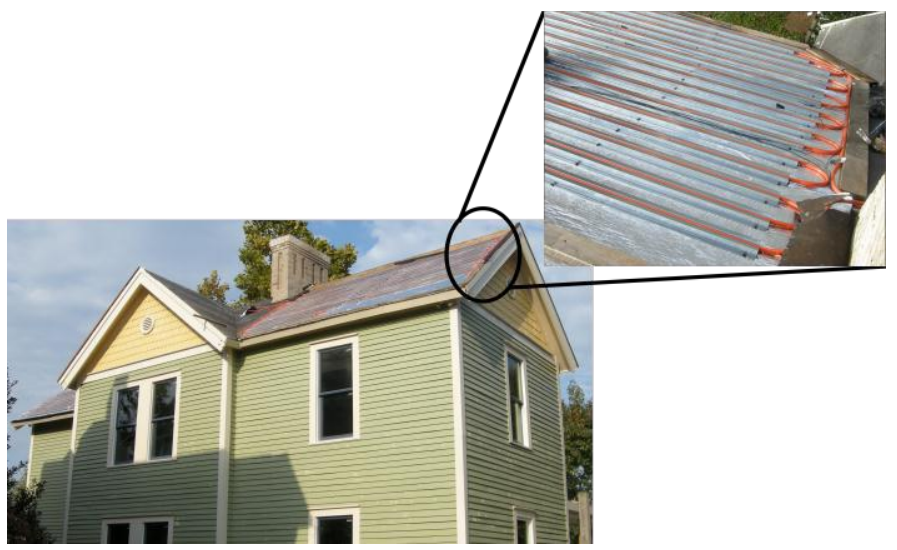

PEX tubing of the solar water heater collector installed underneath the metal roof. 


\section{KEY ENERGY-EFFICIENCY MEASURES}

\section{HVAC:}

- Variable capacity ducted heat pump with 3-ton capacity and an efficiency of 20.5 SEER and 13 HSPF

- Ductwork was insulated with R-6 duct wrap

\section{Envelope:}

- Exterior walls - R16; Attic R-38; Basement walls R-10

- Windows - ENERGY STAR $B U=0.3$, $\mathrm{SHGC}=0.2$

\section{Lighting, Appliances, and Water Heating:}

- Lighting - 78\% CFLs

- Solar water heater with electric back up

For more Information, please visit: www.buildings.energy.gov

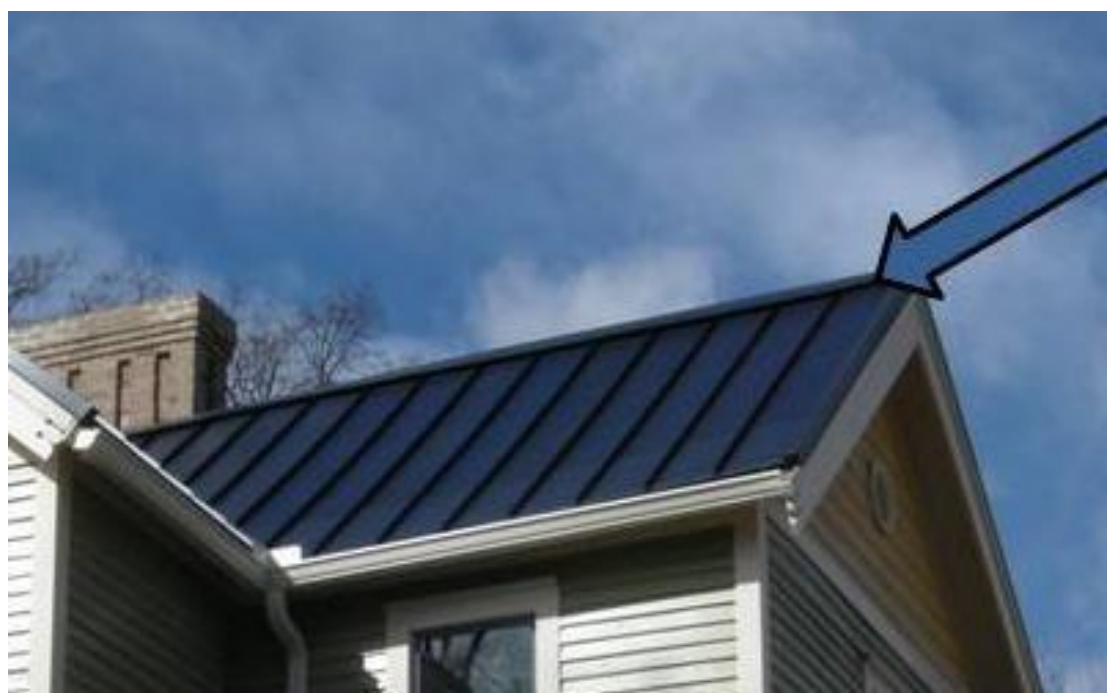

Photograph of $1.4 \mathrm{~kW}_{\text {peak }}$ laminate PV designed to blend in with the standing seam metal roof.

\section{Lessons Learned}

- To decrease air infiltration a continuous house wrap completely covered the walls (underneath the siding) and was embedded into the foam in the closed soffits. In conjunction with the sealed attic roof deck, this continuous air barrier helped decrease the air infiltration into the home.

- Due to restrictions on panels on the roof of this historic home, creative solutions were found to install photovoltaics and a solar thermal water heating system at this site. A $1.4 \mathrm{~kW}_{\text {peak }}$ laminate PV system was installed on the standing seam metal roof and is barely noticeable (see photograph above). PEX tubing of the solar water heater collector was installed underneath the metal roof, out of sight, but still able to capture heat conducted through the metal roof (see photograph on first page).

- Remodeling or major home repair are excellent opportunities to employ energy retrofits with minimal extra cost and inconvenience. The energy retrofit began in conjunction with a full remodel of the turn of the century home.

- The retrofit of a $100+$ year old home can save over $50 \%$ source energy savings.

"The project schedule was delayed about two months due the retrofit process. Deciding to do the retrofit before the design phase would have helped."

- Preservation Organization
The U.S. Department of Energy's Building America program is engineering the American home for energy performance, durability, quality, affordability, and comfort.
Energy Efficiency \& Renewable Energy 


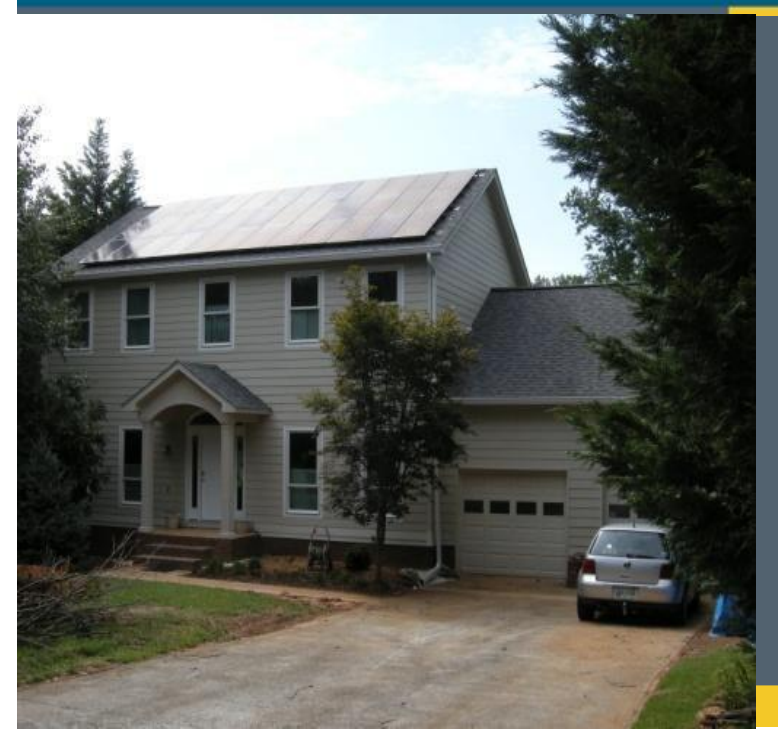

Building America

Efficient Solutions for Existing Homes

\section{Case Study:}

\section{Deep Energy Retrofits in East Tennessee - Summit}

\author{
Knoxville, TN
}

The residential sector used $22 \%$ of the nation's energy in 2010. The

Department of Energy's Building America program has a research goal of demonstrating market-ready energy retrofit packages that reduce home energy use by $30-50 \%$. Oak Ridge National Laboratory (ORNL) contributed to this research goal by spurring and analyzing five residential retrofits in the mixed humid climate around Knoxville, TN. In addition to the Building America goal, ORNL set out to understand why homeowners decide to do retrofits, how much do whole house retrofits actually save and if the retrofits are cost effective.

The owner of the Summit home voluntarily participated in the project with the goal of increasing the energy efficiency of the home. He also felt it was his patriotic duty and that all citizens should strive for a netzero energy home. The Summit home was built in 1995. It is a two story, $3,110 \mathrm{ft}^{2}$ single-family home with 3 bedrooms and 2 and a half bathrooms. Prior to the retrofit ORNL audited the home with various research partners and provided recommendations to the homeowners for retrofit measures. The lessons learned from this deep energy retrofit will help inform future retrofit construction and research.

\section{Pre-retrofit: 119}

HERS index:

Post-retrofit: 23 (w/PV), 69 (w/o

PV)

Annual energy cost savings: $\$ 770$ (w/o PV)

Whole house source energy savings without PV: 104 MMBtu $(33 \%)$

Site energy savings with PV: 110 MMBtu (94\%)

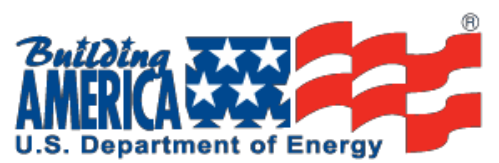

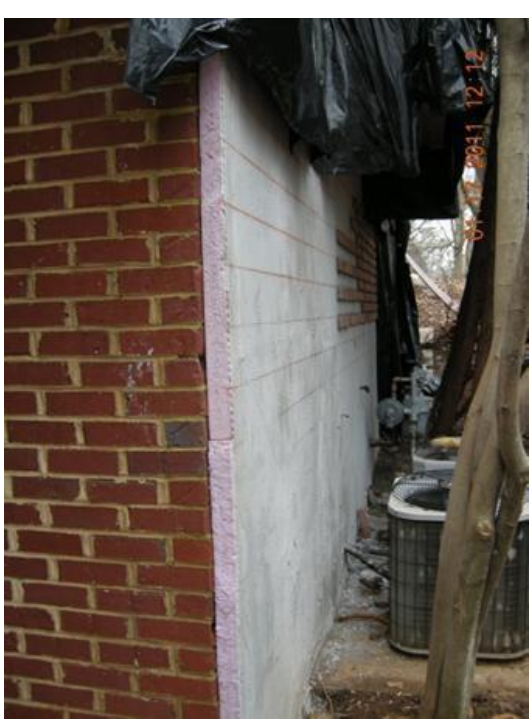

Above-grade basement walls shown during retrofit with foam board and the thin brick veneer being installed. 


\section{KEY ENERGY-EFFICIENCY MEASURES}

\section{HVAC:}

- Two variable speed multi-split heat pumps 3-ton capacity and an efficiency rating of 15 SEER and 8.7 HSPF

- Due to the HVAC multi-split systems, duct work was no longer used.

\section{Envelope:}

- Above-grade exterior foundation insulation

- Added R-3 sheathing to all exterior walls; improved walls adjacent to garage to R-19 (cavity) and R-10 (sheathing)

- Air infiltration was reduced by $58 \%$ from $9.1 \mathrm{ACH}_{50}$ to $3.9 \mathrm{ACH}_{50}$

\section{Lighting, Appliances, and Water Heating:}

- Lighting - 100\% High Efficiency

- $8.5 \mathrm{~kW}_{\text {peak }}$ PV system installed

For more Information, please visit: www.buildings.energy.gov

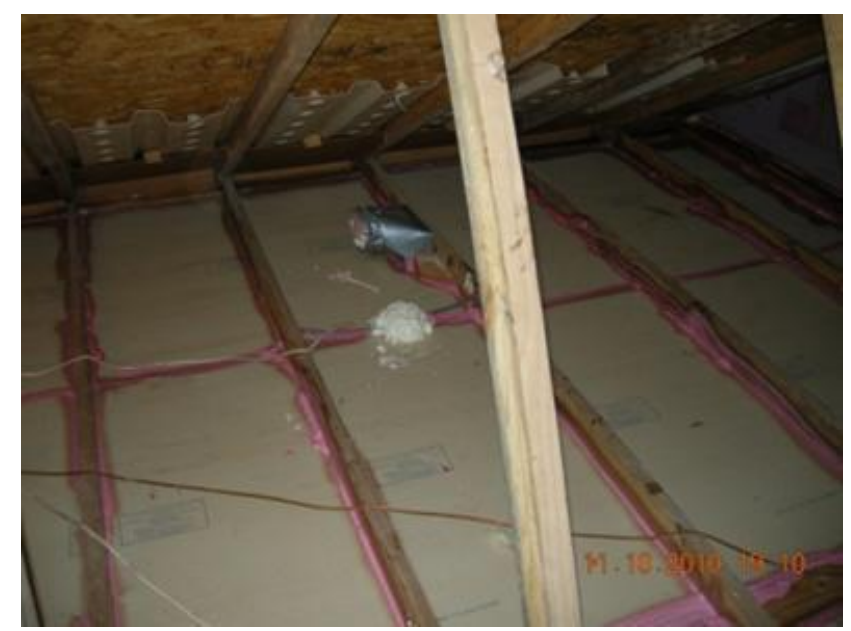

Pink Latex foam used to seal the attic floor.

\section{Lessons Learned}

- Remodeling or major home repair are excellent opportunities to employ energy retrofits with minimal extra cost and inconvenience. The homeowner began the energy retrofit in conjunction with extensive water damage repair.

- Comfort is a major concern for homeowners completing energy retrofits. The Summit homeowners upgraded from 5 tons of capacity with a gas furnace to 6 tons with electric heat pump heating. This upgrade increased comfort (by providing 8 independently controlled zones in the home) but resulted in minimal improvement in energy efficiency. The high first cost of this upgrade with minimal efficiency improvements hurt the cost effectiveness (with only energy savings considered as a benefit) of the retrofit as a whole. However, the homeowner felt increased comfort and room-by-room control outweighed the ratio of energy savings to total cost.

- The homeowners upgraded all double-pane windows to triple- or quadpane windows. Just as the HVAC upgrade, the high first cost of this retrofit decreased the overall cost effectiveness of the retrofit package.

- With an $8.5 \mathrm{~kW}_{\text {peak }}$ photovoltaic system, Summit saved $94 \%$ in site energy savings and had a net utility credit of $\$ 1,000$ due to the TVA Generation Partner program.

"I recommend doing a project in phases where each phase is small enough not to require financing. Small steps lead to big savings." - Homeowner 